\title{
Investigation on the Synthesis and Photocatalytic Property of Uranyl Complexes of the $\beta$-Diketonates Biscatecholamide Ligand
}

\author{
Qingchun Zhang, ${ }^{1}$ Bo Jin, ${ }^{1}$ Rufang Peng, ${ }^{1}$ Xiaofang Wang, ${ }^{1}$ Zhaotao Shi, ${ }^{2}$ Qiangqiang Liu, ${ }^{3}$ \\ Shan Lei, ${ }^{1}$ and Hua Liang ${ }^{1}$ \\ ${ }^{1}$ State Key Laboratory Cultivation Base for Nonmetal Composites and Functional Materials, Southwest University of \\ Science and Technology, Mianyang 621010, China \\ ${ }^{2}$ School of Materials Science and Engineering, Southwest University of Science and Technology, Mianyang 621010, China \\ ${ }^{3}$ Research Center of Laser Fusion, China Academy of Engineering Physics, Mianyang 621010, China \\ Correspondence should be addressed to Bo Jin; jinbo0428@163.com and Rufang Peng; pengrufang@swust.edu.cn
}

Received 28 June 2016; Revised 29 August 2016; Accepted 6 September 2016; Published 29 January 2017

Academic Editor: Jiangbo Yu

Copyright (C) 2017 Qingchun Zhang et al. This is an open access article distributed under the Creative Commons Attribution License, which permits unrestricted use, distribution, and reproduction in any medium, provided the original work is properly cited.

A series of uranyl complexes have been synthesized by reacting hexadentate ligands $\mathrm{CH}_{2}\left[\mathrm{COO}\left(\mathrm{CH}_{2}\right)_{n} \mathrm{CAM} ; n=2,3,4\right]_{2}$ [CAM $\left.=2,3-\mathrm{Ph}(\mathrm{OH})_{2} \mathrm{CONH}\right]$ containing the catecholamide (CAM) group and $\beta$-diketonates framework with uranyl nitrate. They were characterized by FTIR, UV-vis, ${ }^{1} \mathrm{H}$ NMR, XPS, TGA, and elemental analysis. The analysis revealed that oxygen atom of $\beta$-diketonate did not bind to uranyl ion in complexes 1-3. The photocatalytic degradation properties of the target complexes for degradation of rhodamine $\mathrm{B}(\mathrm{RhB})$ were investigated. The result indicated that approximately $74 \%, 71 \%$, and $67 \% \mathrm{RhB}$ were degraded in the presence of complexes 1-3 after about $210 \mathrm{~min}$, respectively. Consequently, complexes 1-3 have excellent photocatalytic degradation property.

\section{Introduction}

In recent years, uranyl complexes have attracted much attention for exploring reactivity and coordination behavior of $5 f$-elements, developing suitable trivalent actinide (An(III)) extractants for nuclear remediation [1], screening highly effective chelators structure for decorporation of trivalent actinide $(\mathrm{An}(\mathrm{III}))$ [2], and investigating applications in the fields of catalysis, ion exchange, sensors, and photochemistry [3-5].

At present, a large number of uranyl complexes have been synthesized due to their diversified property. Nevertheless, the characteristics of organic ligands play a key role in formation process of the uranyl complexes. Multidentates $\beta$-diketonates biscatecholamide ligands [6] have six binding sites due to the $\mathrm{O}$-donor of catechol aromatic ring and $\beta$ diketonates $[7,8]$. As an important chelator for decorporation of uranyl ion, catechol has the favorable stability constant [9,
10]. The $\beta$-diketonates compounds were adequate sensitizers to luminescent lanthanide complexes in which either visible or NIR emission is consecutive with photoinduced energy transfer from the sensitizing ligand [11]. The $\beta$-diketonates catecholamide ligands $\left(\mathrm{H}_{4} \mathrm{~L}^{1-3}\right)$ have been reported as efficient uranyl sequestration agents in neutral $\mathrm{pH}$ aqueous media [6], but the detailed functional properties of their uranyl complexes have not been studied.

Since early 1800 s, the photocatalytic behavior of uranyl complexes has attracted considerable attention. In general, the equatorial plane can be formed between the coordinated atom and the uranyl ion, which appeared to be bulky conjugate system surrounding the rigid rings of ligands centered in uranyl [12]. Then excitation of these species can result in ${ }^{*} \mathrm{UO}_{2}{ }^{2+}$, which is very active and can trigger a variety of redox reactions to decompose the dye molecules [13, 14]. As compared to $\mathrm{TiO}_{2}$, the excited electrons of dye molecules are injected into $\mathrm{TiO}_{2}$ to decompose the dye molecules $[15,16]$. 
It is generally accepted that, in the photocatalytic reaction, the excitation of uranyl complexes is much more efficient than that of the dye molecules. So, we design the new uranyl$\beta$-diketonates biscatecholamide complexes $\left(\mathrm{UO}_{2} \mathrm{~L}^{1-3} \cdot 2 \mathrm{H}_{2} \mathrm{O}\right)$, which may have efficient photocatalytic property. In this paper, three complexes $\mathrm{UO}_{2} \mathrm{~L}^{1-3} \cdot 2 \mathrm{H}_{2} \mathrm{O}$ have been successfully synthesized in the presence of $\mathrm{UO}_{2}\left(\mathrm{NO}_{3}\right)_{2} \cdot 6 \mathrm{H}_{2} \mathrm{O}$ and $\beta$ diketonates biscatecholamide ligand. These complexes were characterized by FTIR spectra, UV-vis spectra, ${ }^{1} \mathrm{H}$ NMR, XPS spectra, and elemental analysis. Then photocatalytic degradation properties of the complexes were also investigated by $\mathrm{RhB}$ as model compound of organic pollutant.

\section{Experimental}

2.1. Materials and Methods. $\mathrm{UO}_{2}\left(\mathrm{NO}_{3}\right)_{2} \cdot 6 \mathrm{H}_{2} \mathrm{O}$ (99.9\%) was purchased from commercial products from HuBei ChuShengWei Chemistry Co., Ltd. All the organic reagents were pure commercial products from Aladdin. The solvents were purchased from Chengdu Kelong Chemical Reagents Co. The 300-400 mesh silica gel was purchased from Qingdao Hailang. ${ }^{1} \mathrm{H}$ NMR and ${ }^{13} \mathrm{C}$ NMR spectra were recorded on Bruker Avance III 600 spectrometer. The FTIR spectra were obtained from Thermo Scientific Nicolet 380 FTIR spectrophotometer. The UV-vis spectra were obtained from Thermo Scientific Evolution 300 spectrophotometer. The XPS spectra were obtained from Thermo ESCALAB 250 electron spectrometer. Mass spectral analyses were conducted using Varian 1200 LC/MS. Elemental analyses of the complexes were carried out on a Vario EL III CHNS analyzer.

2.2. Synthesis of the Ligands. A solution of malonyl dichloride $(1.0 \mathrm{mmol})$ in $\mathrm{CH}_{2} \mathrm{Cl}_{2}(20 \mathrm{~mL})$ was dropped in the solution of 2,3-bis(benzyloxy)- $N$-(hydroxyalkyl)benzamide $(2.0 \mathrm{mmol})$ and $\mathrm{Et}_{3} \mathrm{~N}(2.0 \mathrm{~mL})$ in $\mathrm{CH}_{2} \mathrm{Cl}_{2}(20 \mathrm{~mL})$ under ice bath and vigorous stirring conditions. After evaporation of the solvent, the residue was purified by flash column chromatography. Then deprotection of the hydroxyl groups under $\mathrm{H}_{2}$ and $\mathrm{Pd} / \mathrm{C}$ catalytic conditions in THF resulted in the $\beta$-diketonates biscatecholamide ligands $\mathrm{H}_{4} \mathrm{~L}^{1-3}[6]$.

Bis(2,3-bis(hydroxy)-N-(hydroxyethyl)benzamide)malonate $\left(H_{4} L^{1}\right) .{ }^{1} \mathrm{H}$ NMR $\left(600 \mathrm{MHz}, \mathrm{DMSO}-d_{6}\right): \delta=8.90$ (br s, 2H, CO-NH), 7.25 (dd, $J=7.8,1.2 \mathrm{~Hz}, 2 \mathrm{H}, \mathrm{Ar}-\mathrm{H}), 6.91$ (dd, $J=7.8,1.2 \mathrm{~Hz}, 2 \mathrm{H}, \mathrm{Ar}-\mathrm{H}), 6.67(\mathrm{t}, J=7.8 \mathrm{~Hz}, 2 \mathrm{H}, \mathrm{Ar}-\mathrm{H})$, $4.20\left(\mathrm{t}, J=5.7 \mathrm{~Hz}, 4 \mathrm{H},-\mathrm{CH}_{2}-\right), 3.52\left(\mathrm{~m}, 6 \mathrm{H}, \mathrm{CO}-\mathrm{CH}_{2}-\mathrm{CO}\right.$ and $\left.-\mathrm{CH}_{2}-\right)$. ${ }^{13} \mathrm{C}$ NMR $\left(150 \mathrm{MHz}, \mathrm{DMSO}-d_{6}\right): \delta=170.4$ $(\mathrm{C}=\mathrm{O}), 166.9(\mathrm{C}=\mathrm{O}), 150.0(\mathrm{ArC}), 146.7(\mathrm{ArC}), 119.2(\mathrm{ArCH})$, $118.4(\mathrm{ArCH}), 117.8(\mathrm{ArCH}), 115.3(\mathrm{ArC}), 63.6\left(-\mathrm{CH}_{2}-\right), 41.5$ $\left(-\mathrm{CH}_{2}{ }^{-}\right), 38.3\left(-\mathrm{CH}_{2}-\right)$. FTIR $\left(\mathrm{KBr}, \mathrm{cm}^{-1}\right)$ : 3398, 2957, 2929, $1750,1731,1642,1590,1546,1459$. UV-vis (DMSO, nm): 248, 319. APCI-MS $(m / z): 463.2[\mathrm{M}+\mathrm{H}]^{+}$.

Bis(2,3-bis(hydroxy)-N-(3-hydroxypropyl)benzamide)malonate $\left(H_{4} L^{2}\right) .{ }^{1} \mathrm{H}$ NMR $\left(600 \mathrm{MHz}, \mathrm{DMSO}-d_{6}\right): \delta=12.74$ (br s, 2H, Ar-OH), 9.17 (br s, 2H, Ar-OH), 8.84 (br s, 2H, CO-NH), 7.26 (dd, $J=7.8,1.2 \mathrm{~Hz}, 2 \mathrm{H}, \mathrm{Ar}-\mathrm{H}), 6.90$ (dd, $J=$
7.8, $1.2 \mathrm{~Hz}, 2 \mathrm{H}, \mathrm{Ar}-\mathrm{H}), 6.67$ (t, $J=7.8 \mathrm{~Hz}, 2 \mathrm{H}, \mathrm{Ar}-\mathrm{H}), 4.13$ $\left(\mathrm{t}, J=6.4 \mathrm{~Hz}, 4 \mathrm{H},-\mathrm{CH}_{2}-\right), 3.51\left(\mathrm{~s}, 2 \mathrm{H}, \mathrm{CO}-\mathrm{CH}_{2}-\mathrm{CO}\right), 3.34$ $\left(\mathrm{m}, 4 \mathrm{H},-\mathrm{CH}_{2}-\right), 1.87\left(\mathrm{~m}, 4 \mathrm{H},-\mathrm{CH}_{2}-\right) .{ }^{13} \mathrm{C} \mathrm{NMR}(150 \mathrm{MHz}$, DMSO- $\left.d_{6}\right): \delta=169.8(\mathrm{C}=\mathrm{O}), 166.5(\mathrm{C}=\mathrm{O}), 149.6$ (ArC), 146.2 (ArC), $118.8(\mathrm{ArCH}), 117.8(\mathrm{ArCH}), 117.1(\mathrm{ArCH}), 114.9$ (ArC), $62.8\left(-\mathrm{CH}_{2}-\right), 41.2\left(-\mathrm{CH}_{2}-\right), 35.8\left(-\mathrm{CH}_{2}-\right), 27.9\left(-\mathrm{CH}_{2}^{-}\right)$. FTIR (KBr, cm $\left.{ }^{-1}\right)$ : 3390, 2956, 1747, 1735, 1641, 1591, 1547, 1459. UV-vis (DMSO, nm): 246, 320. APCI-MS $(\mathrm{m} / z): 491.1$ $[\mathrm{M}+\mathrm{H}]^{+}$.

Bis(2,3-bis(hydroxy)-N-(4-hydroxybutyl)benzamide)malonate $\left(\mathrm{H}_{4} \mathrm{~L}^{3}\right) .{ }^{1} \mathrm{H} \mathrm{NMR}\left(600 \mathrm{MHz}, \mathrm{DMSO}-d_{6}\right): \delta=8.80$ (br s, $2 \mathrm{H}$, CO-NH), 7.26 (dd, $J=7.8,1.2 \mathrm{~Hz}, 2 \mathrm{H}, \mathrm{Ar}-\mathrm{H}), 6.99$ (dd, $J=$ 7.8, $1.2 \mathrm{~Hz}, 2 \mathrm{H}, \mathrm{Ar}-\mathrm{H}), 6.66$ (t, $J=7.8 \mathrm{~Hz}, 2 \mathrm{H}, \mathrm{Ar}-\mathrm{H}), 4.09$ $\left(\mathrm{t}, J=6.3 \mathrm{~Hz}, 4 \mathrm{H},-\mathrm{CH}_{2}-\right), 3.50\left(\mathrm{~s}, 2 \mathrm{H}, \mathrm{CO}-\mathrm{CH}_{2}-\mathrm{CO}\right), 3.29$ $\left(\mathrm{dd}, J=12.5,6.3 \mathrm{~Hz}, 4 \mathrm{H},-\mathrm{CH}_{2}-\right), 1.59\left(\mathrm{~m}, 8 \mathrm{H},-\mathrm{CH}_{2}-\mathrm{CH}_{2}^{-}\right)$. ${ }^{13} \mathrm{C}$ NMR $\left(150 \mathrm{MHz}, \mathrm{DMSO}-d_{6}\right): \delta=169.7(\mathrm{C}=\mathrm{O}), 166.6$ $(\mathrm{C}=\mathrm{O}), 149.6(\mathrm{ArC}), 146.2(\mathrm{ArC}), 118.7(\mathrm{ArCH}), 117.8(\mathrm{ArCH})$, 117.0 (ArCH), 114.9 (ArC), $64.5\left(-\mathrm{CH}_{2}-\right), 41.1\left(-\mathrm{CH}_{2}-\right), 38.3$ $\left(-\mathrm{CH}_{2}-\right), 25.5\left(-\mathrm{CH}_{2}-\right), 25.2\left(-\mathrm{CH}_{2}-\right)$. FTIR $\left(\mathrm{KBr}, \mathrm{cm}^{-1}\right)$ : 3399, 2926, 1745, 1735, 1639, 1594, 1545, 1459. UV-vis (DMSO, nm): 248, 322. APCI-MS $(m / z): 519.7[\mathrm{M}+\mathrm{H}]^{+}$.

\subsection{Synthesis of Uranyl Complexes}

Caution! Even though the $\mathrm{UO}_{2}\left(\mathrm{NO}_{3}\right)_{2} \cdot 6 \mathrm{H}_{2} \mathrm{O}$ used in this study contains depleted uranium, standard precautions for handling radioactive substances should be followed.

A solution of $\mathrm{UO}_{2}\left(\mathrm{NO}_{3}\right)_{2} \cdot 6 \mathrm{H}_{2} \mathrm{O}(55.2 \mathrm{mg}, 0.11 \mathrm{mmol})$ in methanol was added to a methanol solution of a $\beta$ diketonates biscatecholamide ligands $\mathrm{H}_{4} \mathrm{~L}^{1-3}(0.1 \mathrm{mmol})$ with stirring. The colorless ligand solution immediately turned orange and shown a strong acidic reaction to $\mathrm{pH}$ paper, indicating the formation of a uranyl complex. Following the addition of 1 or 2 drops of pyridine the transparent reaction mixture became turbid. The solution was then heated at reflux overnight, under nitrogen. The uranyl complexes deposited as orange precipitates, which were collected by centrifugation, washed with methanol, and dried in a vacuum oven and obtained orange power.

$\mathrm{UO}_{2} \mathrm{~L}^{1} \cdot 2 \mathrm{H}_{2} \mathrm{O}$ Complex (1). Yield $72 \%$. The ${ }^{1} \mathrm{H}$ NMR spectra of DMSO- $d_{6}$ at room temperature show that the complex contains the major and minor species (possibly isomers); the ratio was about $5.2: 1 .{ }^{1} \mathrm{H} \mathrm{NMR}\left(600 \mathrm{MHz}\right.$, DMSO- $d_{6}$, major species): $\delta=10.03$ (d, $J=9.4 \mathrm{~Hz}, 2 \mathrm{H}, \mathrm{CO}-\mathrm{NH}), 7.13-7.03(\mathrm{~m}$, $2 \mathrm{H}$, ortho cat- $\mathrm{H}), 6.98-6.88(\mathrm{~m}, 4 \mathrm{H}$, meta and para cat $-\mathrm{H})$, $5.18\left(\mathrm{dd}, J=23.8,12.1 \mathrm{~Hz}, 2 \mathrm{H},-\mathrm{CH}_{2}-\right), 4.78(\mathrm{~d}, J=11.9 \mathrm{~Hz}, 2 \mathrm{H}$, $-\mathrm{CH}_{2}-$ ), $4.00\left(\mathrm{t}, J=12.0 \mathrm{~Hz}, 2 \mathrm{H},-\mathrm{CH}_{2}-\right), 3.63(\mathrm{~d}, J=14.2 \mathrm{~Hz}$, $2 \mathrm{H},-\mathrm{CH}_{2}-$ ), 2.83 (d, J $\left.=17.0 \mathrm{~Hz}, 1 \mathrm{H}, 0.5 \times-\mathrm{COCH}_{2} \mathrm{CO}-\right), 1.71$ $\left(\mathrm{d}, J=17.0 \mathrm{~Hz}, 1 \mathrm{H}, 0.5 \times-\mathrm{COCH}_{2} \mathrm{CO}-\right) .{ }^{1} \mathrm{H} \mathrm{NMR}(600 \mathrm{MHz}$, DMSO- $d_{6}$, minor species): $\delta=10.92(\mathrm{~s}, 2 \mathrm{H}, \mathrm{CO}-\mathrm{NH}), 7.67(\mathrm{~d}, J$ $=7.5 \mathrm{~Hz}, 2 \mathrm{H}$, ortho cat $-\mathrm{H}), 7.44(\mathrm{~d}, J=7.7 \mathrm{~Hz}, 2 \mathrm{H}$, para cat-H), $6.67\left(\mathrm{t}, J=7.8 \mathrm{~Hz}, 2 \mathrm{H}\right.$, meta cat-H), $4.97\left(\mathrm{~b}, 2 \mathrm{H},-\mathrm{CH}_{2}-\right), 4.55$ (b, $\left.2 \mathrm{H},-\mathrm{CH}_{2}-\right), 4.21\left(\mathrm{~b}, 2 \mathrm{H},-\mathrm{CH}_{2}-\right), 3.93\left(\mathrm{~m}, 2 \mathrm{H},-\mathrm{CH}_{2}-\right), 3.07$ (d, $J=17.3 \mathrm{~Hz}, 1 \mathrm{H}, 0.5 \times-\mathrm{COCH}_{2} \mathrm{CO}-$ ), $2.83(\mathrm{~d}, J=17.3 \mathrm{~Hz}, 1 \mathrm{H}$, $\left.0.5 \times-\mathrm{COCH}_{2} \mathrm{CO}-\right)$. FTIR $\left(\mathrm{KBr}, \mathrm{cm}^{-1}\right): 3397,1746,1587,1546$, 1461, 1439, 1350, 1309, 1217, 927, 550. UV-vis (DMSO, nm): 258, 328. Anal. Calcd. for $\mathrm{UO}_{2} \mathrm{C}_{21} \mathrm{H}_{20} \mathrm{~N}_{2} \mathrm{O}_{11}$ (746.40): C, 33.76; $\mathrm{H}$, 2.68; N, 3.75. Found: C, 34.76; H, 2.51; N, 3.69. 


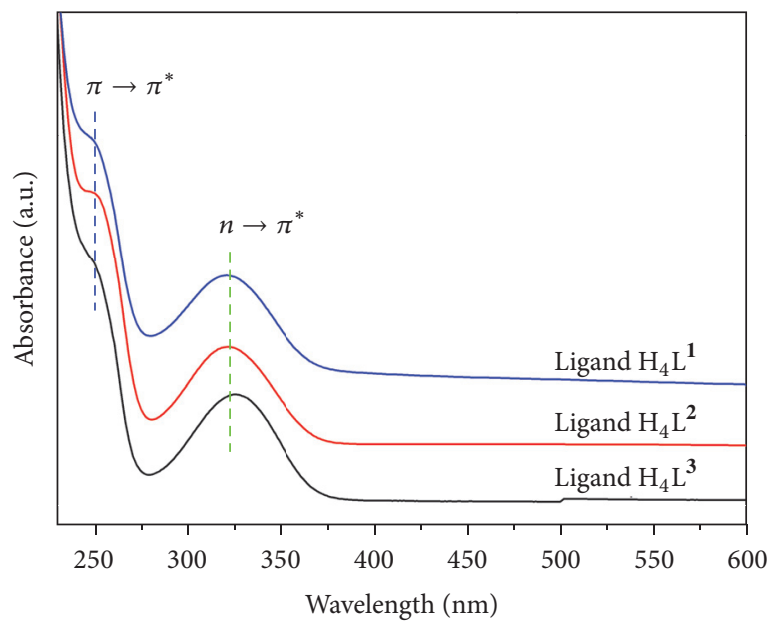

(a)

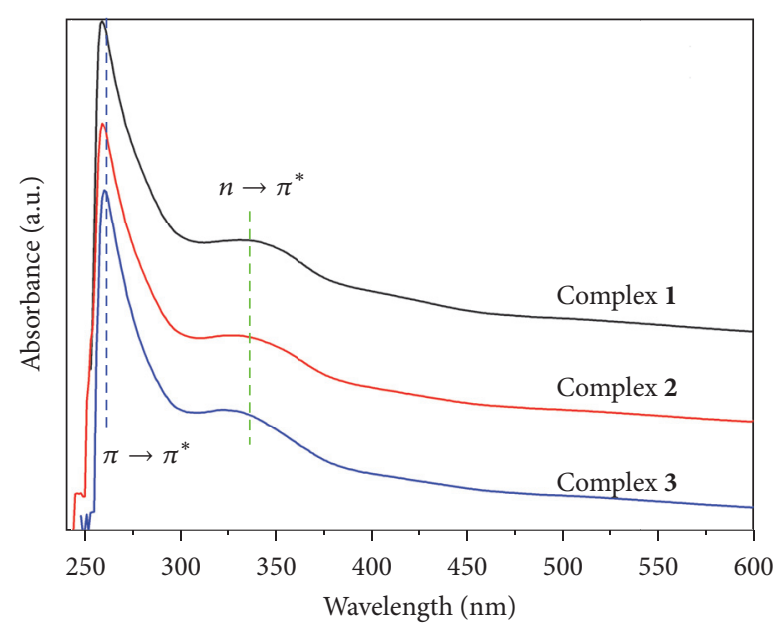

(b)

FIgURE 1: The UV-vis spectra of (a) the free ligands $\mathrm{H}_{4} \mathrm{~L}^{1-3}$ and (b) complexes 1-3.

$\mathrm{UO}_{2} \mathrm{~L}^{2} \cdot 2 \mathrm{H}_{2} \mathrm{O}$ Complex (2). Yield $70 \%$. The ${ }^{1} \mathrm{H}$ NMR spectra of in DMSO- $d_{6}$ at room temperature show that the complex contains the major and minor species (possibly isomers); the minor species signals are too weak to assign. ${ }^{1} \mathrm{H}$ NMR (600 MHz, DMSO- $d_{6}$, major species): $\delta=10.07$ (s, $2 \mathrm{H}, \mathrm{CO}-$ $\mathrm{NH}), 7.04(\mathrm{~m}, 2 \mathrm{H}$, ortho cat- $\mathrm{H}), 6.93(\mathrm{~m}, 4 \mathrm{H}$, meta and para cat-H), $4.60-4.10\left(\mathrm{~m}, 4 \mathrm{H},-\mathrm{CH}_{2}-\right), 4.04-3.78\left(\mathrm{~m}, 4 \mathrm{H},-\mathrm{CH}_{2}\right.$ ), $3.18\left(\mathrm{~d}, J=5.3 \mathrm{~Hz}, 2 \mathrm{H},-\mathrm{COCH}_{2} \mathrm{CO}-\right), 2.29-1.97(\mathrm{~m}, 4 \mathrm{H}$, $-\mathrm{CH}_{2}$-). FTIR $\left(\mathrm{KBr}, \mathrm{cm}^{-1}\right): 3367,1742,1588,1546,1461,1444$, 1346, 1307, 1217, 929, 550. UV-vis (DMSO, nm): 259, 328. Anal. Calcd. for $\mathrm{UO}_{2} \mathrm{C}_{23} \mathrm{H}_{24} \mathrm{~N}_{2} \mathrm{O}_{11}$ (774.46): C, 35.64; $\mathrm{H}, 3.09 ; \mathrm{N}$, 3.62. Found: C, 36.71; H, 2.96; N, 3.59.

$\mathrm{UO}_{2} \mathrm{~L}^{3} \cdot 2 \mathrm{H}_{2} \mathrm{O}$ Complex (3). Yield $74 \%$. The ${ }^{1} \mathrm{H}$ NMR spectra of in DMSO- $d_{6}$ at room temperature show that the complex contains the major and minor species (possibly isomers); the ratio was about $4.1: 1 .{ }^{1} \mathrm{H}$ NMR $\left(600 \mathrm{MHz}\right.$, DMSO- $d_{6}$, major species): $\delta=10.04$ (br s, $2 \mathrm{H}, \mathrm{CO}-\mathrm{NH}), 7.15-7.04(\mathrm{~m}, 2 \mathrm{H}$, ortho cat- $\mathrm{H}), 6.91(\mathrm{~m}, 4 \mathrm{H}$, meta and para cat- $\mathrm{H}), 4.10(\mathrm{~m}, 4 \mathrm{H}$, $\left.\left.\mathrm{CH}_{2}\right)^{-}\right), 3.94\left(\mathrm{~m}, 4 \mathrm{H},-\mathrm{CH}_{2}-\right), 3.19(\mathrm{~d}, J=16.0 \mathrm{~Hz}, 1 \mathrm{H}, 0.5 \times-$ $\mathrm{COCH}_{2} \mathrm{CO}-$ ), 3.08 (d, $J=16.0 \mathrm{~Hz}, 1 \mathrm{H}, 0.5 \times-\mathrm{COCH}_{2} \mathrm{CO}-$ ), 1.78-1.56 (m, 8H, - $\left.\mathrm{CH}_{2} \mathrm{CH}_{2}-\right)$. ${ }^{1} \mathrm{H}$ NMR $(600 \mathrm{MHz}$, DMSO$d_{6}$, minor species): $\delta=10.54$ (br s, $2 \mathrm{H}, \mathrm{CO}-\mathrm{NH}$ ), 7.52 (dd, $J=7.6,1.7 \mathrm{~Hz}, 2 \mathrm{H}$, ortho cat-H), 7.49 (dd, $J=7.9,1.7 \mathrm{~Hz}$, $2 \mathrm{H}$, para cat-H), $6.66(\mathrm{t}, J=7.8 \mathrm{~Hz}, 2 \mathrm{H}$, meta cat- $\mathrm{H}), 4.55$ $\left(\mathrm{m}, 8 \mathrm{H},-\mathrm{CH}_{2}-\right), 2.61$ (s, $\left.1 \mathrm{H}, 0.5 \times-\mathrm{COCH}_{2} \mathrm{CO}-\right), 2.38(\mathrm{~s}$, $\left.1 \mathrm{H}, 0.5 \times-\mathrm{COCH}_{2} \mathrm{CO}-\right), 1.91-1.79\left(\mathrm{~m}, 8 \mathrm{H},-\mathrm{CH}_{2} \mathrm{CH}_{2}-\right.$ ). FTIR $\left(\mathrm{KBr}, \mathrm{cm}^{-1}\right): 3390,1742,1588,1546,1461,1444,1342,1309$, 1218, 927, 550. UV-vis (DMSO, nm): 259, 326. Anal. Calcd. for $\mathrm{UO}_{2} \mathrm{C}_{25} \mathrm{H}_{28} \mathrm{~N}_{2} \mathrm{O}_{11}$ (802.51): C, 37.38; H, 3.49; N, 3.49. Found: C, 38.45; H, 3.41; N, 3.43.

\section{Results and Discussion}

3.1. UV-Vis Spectra Analysis. The UV-vis spectra of the ligands $\mathrm{H}_{4} \mathrm{~L}^{1-3}$ and their corresponding target uranyl complexes 1-3 were recorded in DMSO solution (Figure 1), and the data were summarized in Table 1 . It was shown from Table 1
TABLE 1: UV-vis spectra data of the ligands and of target complexes.

\begin{tabular}{lccc}
\hline Ligands & $\lambda_{\max }(\mathrm{nm})$ & Uranyl complex & $\lambda_{\max }(\mathrm{nm})$ \\
\hline $\mathrm{H}_{4} \mathrm{~L}^{1}$ & 248,319 & Complex 1 & 258,328 \\
$\mathrm{H}_{4} \mathrm{~L}^{2}$ & 246,320 & Complex 2 & 259,328 \\
$\mathrm{H}_{4} \mathrm{~L}^{3}$ & 248,322 & Complex 3 & 259,326 \\
\hline
\end{tabular}

that all free ligands $\pi \rightarrow \pi^{*}$ transitions absorption bands were in the range of $246-248 \mathrm{~nm}$ and $n \rightarrow \pi^{*}$ transitions absorption bands in the range of $319-322 \mathrm{~nm}$. It was found that the $\pi \rightarrow \pi^{*}$ and $n \rightarrow \pi^{*}$ transitions of complexes were slightly red-shifted as compared to the $\pi \rightarrow \pi^{*}$ and $n \rightarrow$ $\pi^{*}$ transitions of ligands $\mathrm{H}_{4} \mathrm{~L}^{1-3}$ and had absorptions in the visible regions $(380-450 \mathrm{~nm})$, which was ascribed to charge transfer within the $\mathrm{U}=\mathrm{O}$ double bonds and the ligand to metal charge transfer (LMCT) between the oxygen atoms of the coordinating ligands and the empty orbital of the uranyl ion [17-19]. These results show that the $\mathrm{H}_{4} \mathrm{~L}^{1-3}$ take part in coordination with uranyl ion.

3.2. FTIR Spectra Analysis. The FTIR spectra of the ligands $\mathrm{H}_{4} \mathrm{~L}^{1-3}$ and their corresponding target uranyl complexes were recorded in the region $4000-400 \mathrm{~cm}^{-1}$, which were studied to obtain information on the oxygen-to-uranyl coordination from the shift of the C-O stretching with respect to the nonbonded ligands. Since the FTIR spectra of all ligands have shown similar features, the FTIR spectra of ligands $\mathrm{H}_{4} \mathrm{~L}^{1}$ as well as their corresponding complex $\mathbf{1}$ were selected for illustration for comparison reasons shown in Figure 2(a) and all complexes 1-3 are shown in Figure 2(b). The selected vibrations of the ligands $\mathrm{H}_{4} \mathrm{~L}^{1-3}$ and their corresponding complexes studied, together with the suggested assignments, were listed in Table 2.

As shown in Table 2, the bands at $1746-1750 \mathrm{~cm}^{-1}$ for the free ligands were assigned to the $\mathrm{C}=\mathrm{O}$ stretching vibration of $\beta$-diketonate and the bands at $1742-1746 \mathrm{~cm}^{-1}$ for the 


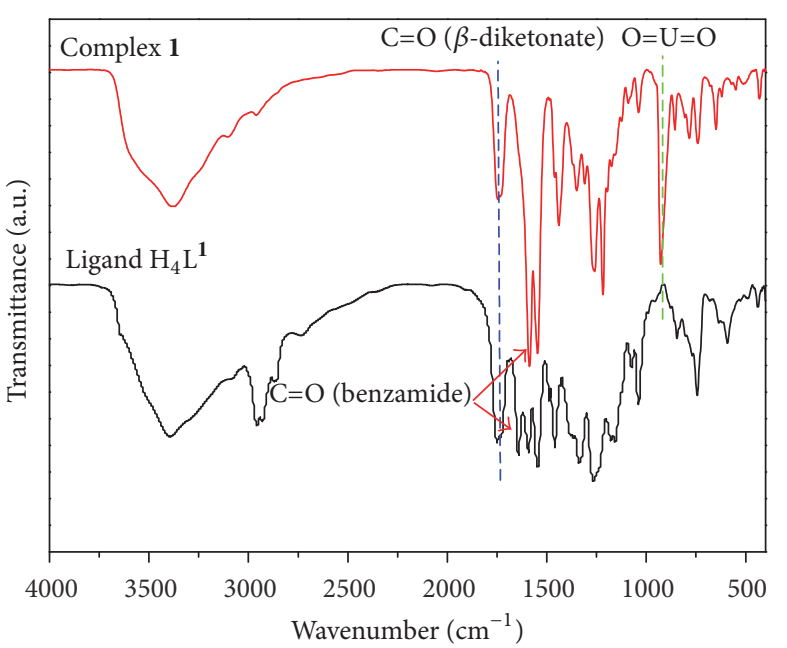

(a)

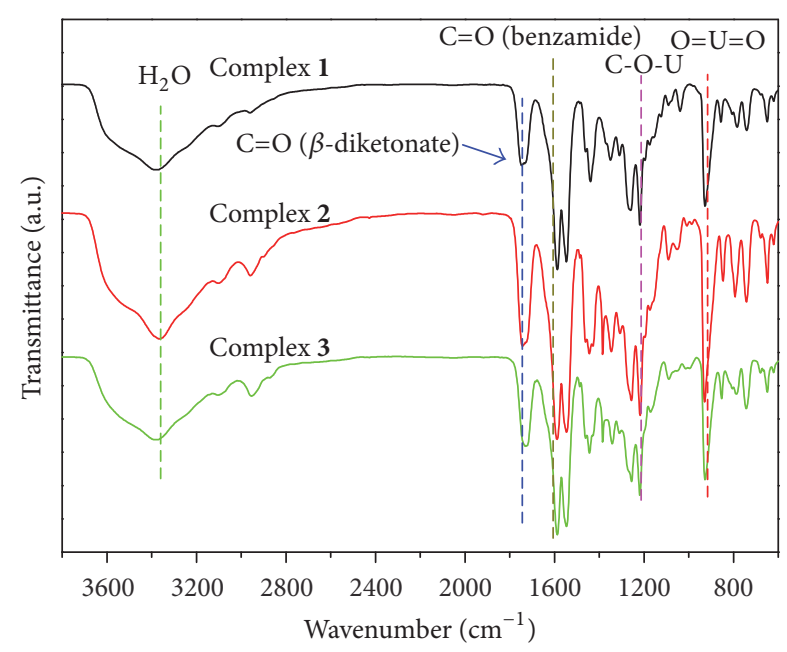

(b)

FIgURE 2: The FTIR spectra of (a) the free ligand $\mathrm{H}_{4} \mathrm{~L}^{1}$ and complex $\mathbf{1}$ and (b) complexes 1-3.

TABLE 2: The FTIR spectral frequencies $\left(\mathrm{cm}^{-1}\right)$ and tentative assignments for the free ligands and uranyl complexes.

\begin{tabular}{|c|c|c|c|c|c|c|}
\hline $\mathrm{H}_{4} \mathrm{~L}^{1}$ & Complex 1 & $\mathrm{H}_{4} \mathrm{~L}^{2}$ & Complex 2 & $\mathrm{H}_{4} \mathrm{~L}^{3}$ & Complex 3 & Assignment of vibration \\
\hline 3398 & 3379 & 3397 & 3367 & 3400 & 3390 & $v(\mathrm{OH})$ \\
\hline 3104,2957 & 3103,2961 & 3094,2956 & 3101,2958 & 3083,2927 & 3102,2954 & $\nu(\mathrm{C}-\mathrm{H})$ \\
\hline 1750 & 1746 & 1747 & 1742 & 1746 & 1742 & $\nu(\mathrm{C}=\mathrm{O})(\beta$-diketonate $)$ \\
\hline 1643 & 1588 & 1641 & 1587 & 1640 & 1587 & $\nu(\mathrm{C}=\mathrm{O})$ \\
\hline 1547 & 1546 & 1547 & 1546 & 1546 & 1546 & $\delta(\mathrm{C}-\mathrm{N}-\mathrm{H})$ \\
\hline 1488 & 1461 & 1487 & 1461 & 1487 & 1461 & $\delta\left(\mathrm{CH}_{2}\right) \mathrm{s}$ \\
\hline 1460 & 1439 & 1460 & 1444 & 1460 & 1444 & $\delta\left(\mathrm{CH}_{2}\right) \mathrm{s}$ \\
\hline 1364 & 1367 & 1361 & 1384 & 1361 & 1384 & $\delta(\mathrm{O}-\mathrm{H})$ \\
\hline 1337 & 1350 & 1337 & 1346 & 1334 & 1342 & $\nu(\mathrm{C}-\mathrm{N})$ \\
\hline- & 1309 & - & 1307 & - & 1309 & $\nu(\mathrm{C}-\mathrm{N})$ and $\delta(\mathrm{N}-\mathrm{H})$ \\
\hline 1266 & 1260 & 1266 & 1256 & 1266 & 1256 & $\nu(\mathrm{C}-\mathrm{O})$ \\
\hline- & 1217 & - & 1217 & - & 1218 & $v(\mathrm{C}-\mathrm{O}-\mathrm{U})$ \\
\hline 1178 & 1174 & 1177 & 1173 & 1171 & 1171 & $v_{\mathrm{as}}(\mathrm{C}-\mathrm{O}-\mathrm{C})$ \\
\hline 1156 & 1157 & 1158 & - & 1157 & - & $\delta(\mathrm{C}-\mathrm{O})$ \\
\hline 1073 & 1091 & 1072 & 1090 & 1069 & 1089 & $\nu_{s}(\mathrm{C}-\mathrm{O}-\mathrm{C})$ \\
\hline 1038 & 1039 & 1038 & 1052 & 1045 & 1053 & $\delta(\mathrm{C}-\mathrm{H})$ \\
\hline- & 927 & - & 929 & - & 927 & $\nu(\mathrm{U}=\mathrm{O})$ as \\
\hline 845 & 856 & 834 & 847 & 842 & 853 & $\delta(\mathrm{C}-\mathrm{H})$ \\
\hline 767,743 & 783,740 & 786,743 & 793,742 & 775,742 & 788,743 & $\delta(\mathrm{C}-\mathrm{H})$ (benzene ring) \\
\hline- & 550 & - & 550 & - & 550 & $\nu(\mathrm{U}=\mathrm{O}) \mathrm{s}$ \\
\hline
\end{tabular}

corresponding complexes; there is hardly any red shifts to form enol tautomers in complexes [7, 20-22], which confirmed that oxygen atoms of carbonyl group of $\beta$-diketonate did not bind to uranyl ion. The bands at $1640-1643 \mathrm{~cm}^{-1}$ were assigned to the $\mathrm{C}=\mathrm{O}$ stretching vibration of amide groups of free ligands, which shifted to $1588 \mathrm{~cm}^{-1}$ in its corresponding complexes; meanwhile, the peaks at $1266 \mathrm{~cm}^{-1}$ were attributed to the $\mathrm{C}-\mathrm{O}$ stretching vibration of catechol units shifted to $1256-1260 \mathrm{~cm}^{-1}$ for their complexes, which indicated that oxygen atoms of phenolic hydroxyl take part in coordination with uranyl ion. In addition, the characteristic absorption peaks of C-N groups at $1334-1337 \mathrm{~cm}^{-1}$ shifted to $1342-1350 \mathrm{~cm}^{-1}$ in their corresponding complexes, showing formation of strong hydrogen bond between hydrogen atoms of amide groups and oxygen atoms of phenolic hydroxyls $[23,24]$. Frequencies of the stretching and deformation vibrations of the $\mathrm{C}=\mathrm{C}, \mathrm{C}-\mathrm{H}$ groups of the benzene rings were also observed. The FTIR spectra of all complexes show strong absorption bands between 927 and $929 \mathrm{~cm}^{-1}$ and weak absorption bands in $550 \mathrm{~cm}^{-1}$. The bands at 927 and $550 \mathrm{~cm}^{-1}$ were assigned to the asymmetric stretching modes of the uranyl moiety [25-27]. Therefore, analytical results of the 


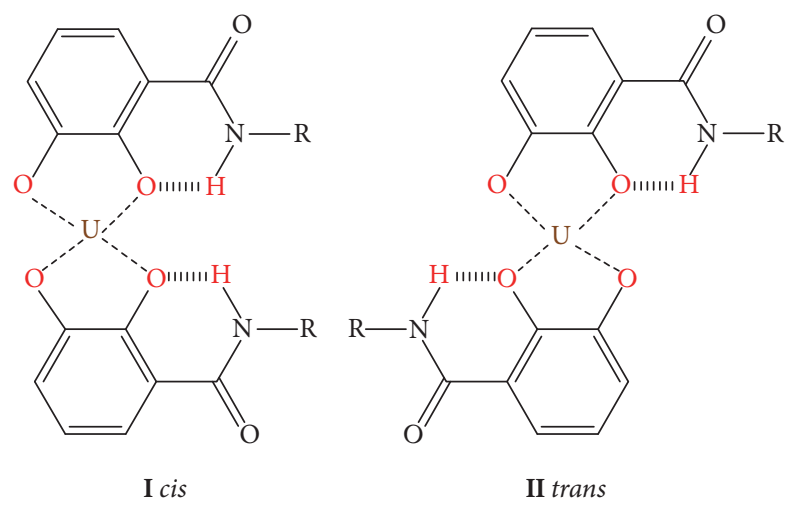

FIgUre 3: Possible geometric isomers of uranyl complexes with two asymmetrically substituted catecholate ligands and uranyl oxo atoms omitted for clarity.

FTIR spectra indicated uranyl ion complexes were to be obtained.

3.3. Proton NMR Spectra Analysis. The development of $\mathrm{H}_{4} \mathrm{~L}^{1-3}$ evolved from the following considerations. The dialkyl malonates spacer not only provides two coordination sites but also enhances the less rigidity and preorientation of the compound and should therefore favor the encapsulation of a uranyl ion unit. Furthermore, model studies show that steric strain in the predisposed ligand reduces the number of possible geometric isomers. For an octahedral liner uranyl complex of an asymmetrically substituted catecholamide ligand there are two conceivable geometrical isomers as shown in Figure 3. So the room-temperature ${ }^{1} \mathrm{H}$ NMR spectra of complexes 1-3 compared with free $\mathrm{H}_{4} \mathrm{~L}^{1-3}$ have shown complex splitting.

The ${ }^{1} \mathrm{H}$ NMR spectra of all ligands and corresponding uranyl complexes have shown similar features. The complexes in DMSO- $d_{6}$ at room temperature have shown that the complexes contain the major and minor species (possibly isomers a and $b$, resp.). The ${ }^{1} \mathrm{H}$ NMR spectra of $\mathrm{H}_{4} \mathrm{~L}^{1}$ as well as their corresponding complex $\mathbf{1}$ were selected for illustration and shown in Figure 4. The resonance signals of amide protons of the major species isomers shifted from $8.90 \mathrm{ppm}$ to $10.02 \mathrm{ppm}$, since the downfield chemical shifts of amide protons are generally interpreted in terms of strong hydrogen bonding $[23,24]$, as shown in Figure 3. The resonance signals of catechol protons of the major species isomers of complex 1 showing two peaks at $7.13-7.03(\mathrm{~m}, 2 \mathrm{H}$, ortho cat- $\mathrm{H})$ and 6.98-6.88 (m, $4 \mathrm{H}$, meta and para cat- $\mathrm{H})$, compared with the free ligand $\mathrm{H}_{4} \mathrm{~L}^{1}$, have appreciable changes and downfield shifts of the aromatic proton resonances of the catechol rings. Similarly, the changes in the level of the signals of the protons of the linker were also shift, turning into complex splitting due to the proximity of the uranyl ion nearby the altered protons. The resonance signals of the methylene protons of the major species isomers showed four peaks at 5.18 (dd, $J$ $\left.=23.8,12.1 \mathrm{~Hz}, 2 \mathrm{H},-\mathrm{CH}_{2}-\right), 4.78\left(\mathrm{~d}, J=11.9 \mathrm{~Hz}, 2 \mathrm{H},-\mathrm{CH}_{2}-\right.$ ), $4.00\left(\mathrm{t}, J=12.0 \mathrm{~Hz}, 2 \mathrm{H},-\mathrm{CH}_{2}-\right)$, and $3.63(\mathrm{~d}, J=14.2 \mathrm{~Hz}$, $2 \mathrm{H},-\mathrm{CH}_{2}-$ ). And the active methylene of $\beta$-diketonates shows
TABLE 3: Binding energy (eV) of complexes 1-3 and splitting value of $\mathrm{U} 4 \mathrm{f}$.

\begin{tabular}{lcccccc}
\hline $\begin{array}{l}\text { Uranyl } \\
\text { complex }\end{array}$ & $\mathrm{O} 1 \mathrm{~s}$ & $\mathrm{C} 1 \mathrm{~s}$ & $\mathrm{~N} 1 \mathrm{~s}$ & ${\mathrm{U} 4 \mathrm{f}_{5 / 2}}$ & ${\mathrm{U} 4 \mathrm{f}_{7 / 2}}$ & $\begin{array}{c}\text { Splitting } \\
\text { value }\end{array}$ \\
\hline Complex 1 & 531.26 & 284.26 & 399.66 & 392.46 & 381.66 & 10.80 \\
Complex 2 & 531.71 & 284.71 & 399.62 & 392.43 & 381.61 & 10.82 \\
Complex 3 & 531.66 & 284.66 & 399.61 & 392.41 & 381.51 & 10.90 \\
\hline
\end{tabular}

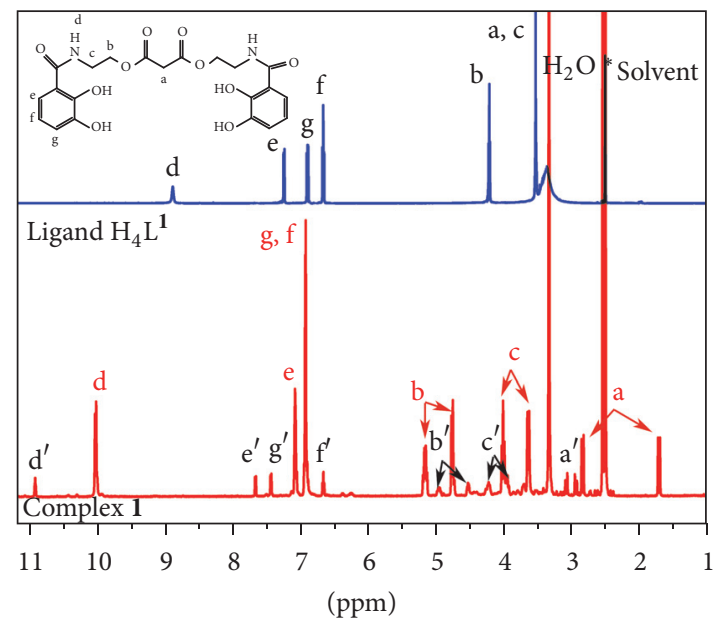

Figure 4: The ${ }^{1} \mathrm{H}$ NMR spectra of ligand $\mathrm{H}_{4} \mathrm{~L}^{1}$ and of complex 1 .

two double peaks at $2.83(\mathrm{~d}, J=17.0 \mathrm{~Hz}, 1 \mathrm{H})$ and $1.71(\mathrm{~d}, J=$ $17.0 \mathrm{~Hz}, 1 \mathrm{H}$ ), but generally, mental complexes present a singlet peak at 5.0-8.0 ppm for the enol tautomers of $\beta$-diketonates $[20,28-30]$. It confirmed that oxygen atom of $\beta$-diketonate did not bind to uranyl ion, also indicated by the FTIR spectra analysis.

3.4. XPS Spectra Analysis. The XPS spectra of the samples were conducted at $10 \mathrm{KV}$ and $5 \mathrm{~mA}$ under $10^{-8} \mathrm{~Pa}$ residual pressure. The peak energies were corrected with $\mathrm{C} 1 \mathrm{~s}$ peak at $284.6 \mathrm{eV}$ as a reference. The recorded lines $(\mathrm{C} 1 \mathrm{~s}, \mathrm{O} 1 \mathrm{~s}, \mathrm{~N} 1 \mathrm{~s}$, and $\mathrm{U} 4 \mathrm{f}$ ) were fitted using the XPSpeak program after the background subtraction.

To study the interaction of uranyl with ligands $\mathrm{H}_{4} \mathrm{~L}^{1-3}$, XPS spectra were recorded for complexes 1-3. The O 1s, C $1 \mathrm{~s}, \mathrm{~N} 1 \mathrm{~s}, \mathrm{U} 4 \mathrm{~d}$, and $\mathrm{U} 4 \mathrm{f}$ spectra were shown in Figure 5. Uranyl coordination reaction was observed in complexes evidenced by the appearance of doublet peaks of $U 4 \mathrm{f}_{5 / 2}$ and $\mathrm{U} 4 \mathrm{f}_{7 / 2}$ with a splitting value of $10.80-10.90 \mathrm{eV}$. The values of the binding energies of $\mathrm{O} 1 \mathrm{~s}, \mathrm{C} 1 \mathrm{~s}, \mathrm{~N} 1 \mathrm{~s}, \mathrm{U} 4 \mathrm{f}_{5 / 2}$, and $U 4 f_{7 / 2}$ and the splitting values of the $U$ if spectra were shown in Table 3 . The $\mathrm{O}$ 1s and $\mathrm{U}$ 4f spectra of complexes 1-3 were shown in Figure 6. The peak fitting results of the $\mathrm{O}$ 1s and $\mathrm{U} 4 \mathrm{f}$ were shown in Table 4. Because XPS is not a quantitative analysis method, these data could be used for semiquantitative analysis of the distribution of multicomponent $[31,32]$. 
TABLE 4: The peak fitting results of the $\mathrm{O} 1 \mathrm{~s}, \mathrm{U} 4 \mathrm{f}_{7 / 2}$ of complexes 1-3.

\begin{tabular}{|c|c|c|c|c|c|c|c|c|c|}
\hline \multirow{2}{*}{$\begin{array}{l}\text { Core } \\
\text { levels }\end{array}$} & \multicolumn{3}{|c|}{ Complex 1} & \multicolumn{3}{|c|}{ Complex 2} & \multicolumn{3}{|c|}{ Complex 3} \\
\hline & $\begin{array}{l}\text { Binding } \\
\text { energy }(\mathrm{eV})\end{array}$ & FWHW $(\mathrm{eV})$ & Area & $\begin{array}{c}\text { Binding } \\
\text { energy }(\mathrm{eV})\end{array}$ & FWHW $(\mathrm{eV})$ & Area & $\begin{array}{c}\text { Binding } \\
\text { energy }(\mathrm{eV})\end{array}$ & FWHW $(\mathrm{eV})$ & Area \\
\hline \multirow{6}{*}{ O 1s } & 533.85 & 1.31 & 1468.15 & 533.98 & 2.13 & 7315.93 & 534.34 & 1.10 & 1318.23 \\
\hline & 533.10 & 1.42 & 6015.89 & 533.50 & 1.3 & 5996.96 & 533.56 & 0.87 & 2983.22 \\
\hline & 532.60 & 1.08 & 6718.25 & 532.70 & 1.06 & 6697.41 & 532.78 & 0.99 & 5832.76 \\
\hline & 532.10 & 1.14 & 7356.14 & 532.30 & 1.13 & 7107.48 & 532.22 & 1.01 & 6766.91 \\
\hline & 531.45 & 1.21 & 16239.1 & 531.60 & 1.20 & 15224.1 & 531.47 & 1.2 & 13254.9 \\
\hline & 530.65 & 1.52 & 8646.69 & 530.69 & 1.49 & 8633.66 & 530.47 & 1.58 & 8728.48 \\
\hline \multirow{2}{*}{$\mathrm{U} 4 \mathrm{f}_{7 / 2}$} & 384.49 & 3.78 & 12770.3 & 384.79 & 4.33 & 17262.9 & 384.80 & 4.12 & 13500.5 \\
\hline & 382.10 & 2.63 & 36018.1 & 382.22 & 2.84 & 45319.6 & 382.20 & 2.74 & 38513.2 \\
\hline
\end{tabular}

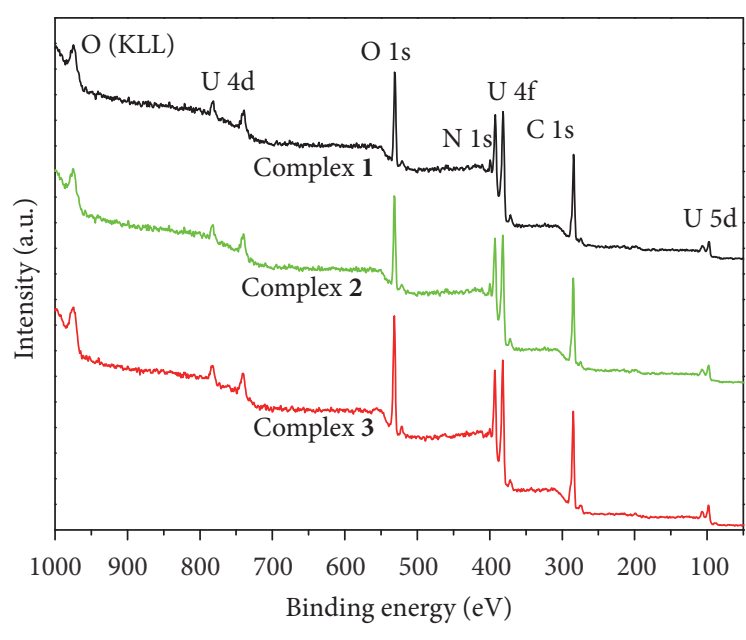

FIGURE 5: XPS survey scans of complexes 1-3.

As shown in Figure 6(a), it was observed that complexes 1-3 presented six main components $O$ 1s spectra for oxygen functionalities. The six peaks position at $530.50-530.69 \mathrm{eV}(\mathrm{O}=\mathrm{U}=\mathrm{O})[33,34], 531.40-531.55 \mathrm{eV}$ (C$\mathrm{O}-\mathrm{U}), 532.20-532.33 \mathrm{eV}$ ( $\mathrm{C}=\mathrm{O}$ of $\beta$-diketonate), $532.60-$ $532.80 \mathrm{eV}$ (C-O-C), 533.40-533.50 eV ( $\mathrm{C}=\mathrm{O}$ of benzamide), and $533.90-534.00 \mathrm{eV}$ (adsorbed $\mathrm{H}_{2} \mathrm{O}$ ) [35] was observed. And the relative intensities of $\mathrm{C}-\mathrm{O}-\mathrm{U}$ were significantly higher than other oxygen functionalities; meanwhile, the presence of the $\mathrm{U}=\mathrm{O}$ bonds was confirmed, as expected.

The $\mathrm{U}_{4 / 2} \mathrm{f}_{7 / 2}$ spectra were deconvoluted into two components: the peak corresponding to the free uranyl ion that occurred at $381.05 \mathrm{eV}$ and the peak of complexes 1-3 that occurred at 382.10-382.22 eV, as shown in Figure 6(b).

From the above discussion, it is clear that the ligands $\mathrm{H}_{4} \mathrm{~L}^{1-3}$ complexation of uranyl ion occurred with the catecholamide moieties.

3.5. Thermal Properties. To examine the thermal stability of complexes 1-3, thermal gravimetric analysis (TGA) was carried out at a heating rate of $10^{\circ} \mathrm{C} \mathrm{min}^{-1}$ under the conditions of $\mathrm{N}_{2}$ atmosphere with the temperature range from
25 to $1100^{\circ} \mathrm{C}$ (Figure 7). The TGA curves of complexes 13 show two steps to weight loss. The first weight loss in the range of $120-220^{\circ} \mathrm{C}$ should be attributed to the loss of two coordinated water molecules with a percentage weight loss (obs. 5.1\%, 4.9\%, and 4.8\%; calcd. 4.82\%, 4.65\%, and $4.49 \%)$ of complexes 1-3, respectively. The second weight loss in the range of $250-1050^{\circ} \mathrm{C}$ is attributed to the loss of biscatecholamide ligands with a percentage weight loss (obs. $55.1 \%, 57.6 \%$, and $60.0 \%$; calcd. $56.86 \%, 58.42 \%$, and $59.87 \%$ ) of complexes 1-3, respectively. The percentage weight of final residue was in good agreement with the calculated value by the stoichiometric chemical formula $\mathrm{UO}_{3}$.

3.6. Photocatalytic Activity. As we know, methyl blue, methyl orange, and RhB dyes have been widely used in textile, printing, paper, and pharmaceutical industries, causing serious pollution to the environment at the same time [35-38]. In this work, we selected $\mathrm{RhB}$ as model compound of organic pollutant to investigate the degradation efficiency using complexes 1-3 as catalysts. To rule out the possibility that the photocatalytic activity of the complex arises from molecular or oligomeric species formed through dissolution of the solid samples in the photocatalytic reaction systems, control experiments were conducted. We subjected the catalysts to UV light and continuous stirring in water for $3 \mathrm{~h}$ and tested the photocatalytic activity of the solution after filtering off the solid materials. No catalytic activity was observed for the solution. Then filtrates residue was added into fresh $\mathrm{RhB}$ for catalysis testing. During the degradation process, a $15 \mathrm{~W} \mathrm{Hg}$ lamp was used as the UV light source. $10 \mathrm{mg}$ of catalyst was dispersed in $100 \mathrm{~mL}$ of $10 \mathrm{mg} \mathrm{L}^{-1} \mathrm{RhB}$ solution under ultrasonication for $15 \mathrm{~min}$. A UV-vis spectrophotometer was used to monitor the reaction under the wavelength of $554 \mathrm{~nm}$ and continuously at $30 \mathrm{~min}$ intervals until the reaction reached steady state.

Figures $8(a)-8(c)$ show that the intensity characteristic absorption of $\mathrm{RhB}$ had obviously decreased in the presence of complexes 1-3 by the UV light irradiation. As it is shown in Figure 9(a), for comparison, the self-degradation of RhB was also assessed under the same experimental conditions. It obviously revealed that, without the solid catalyst in the reaction system, the $\mathrm{RhB}$ hardly degraded in $210 \mathrm{~min}$ of 


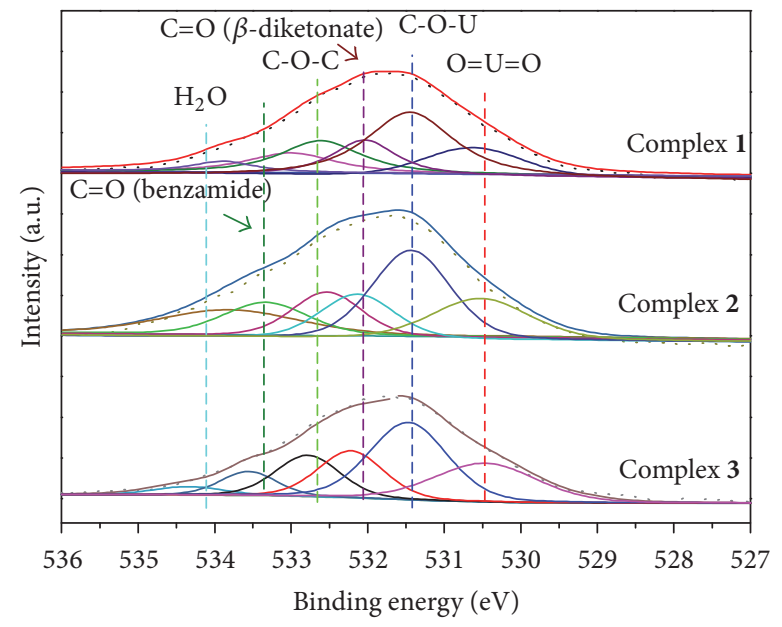

(a)

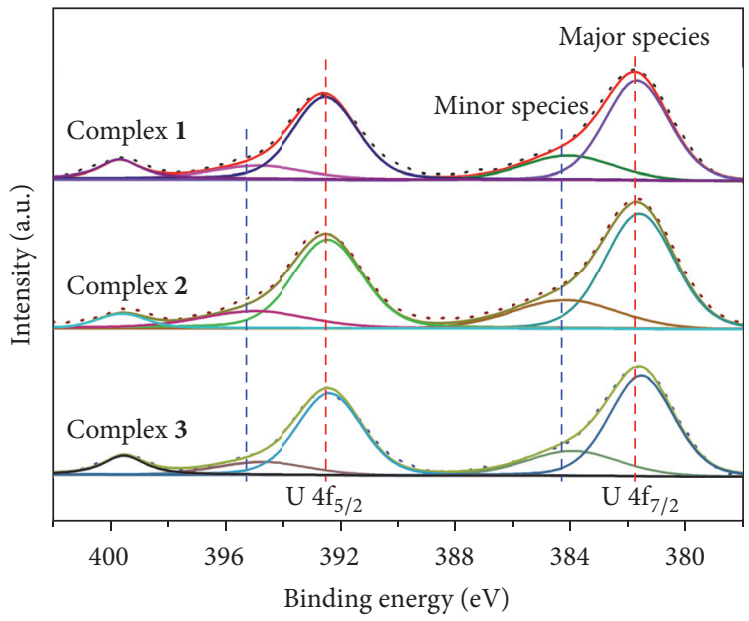

(b)

Figure 6: Curves fitted high resolution scans of (a) $\mathrm{O}$ 1s and (b) $\mathrm{U}$ 4f of complexes 1-3.

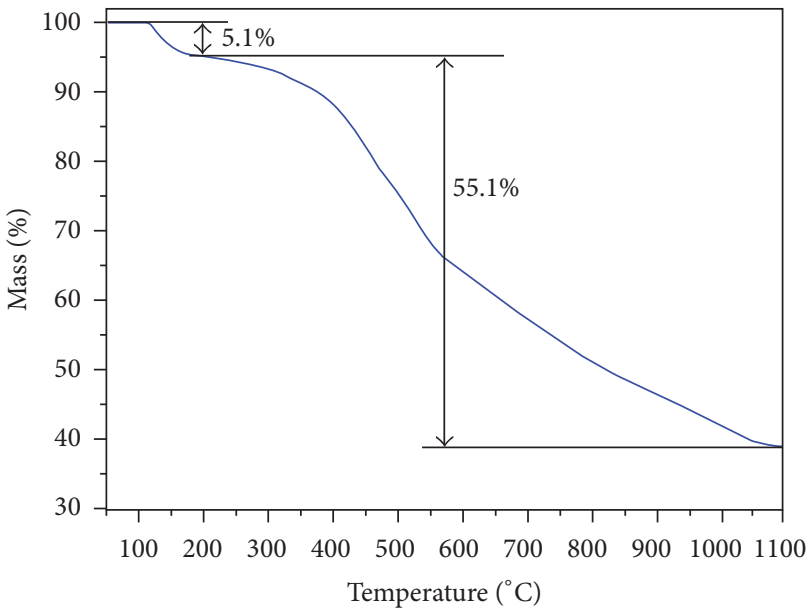

(a)

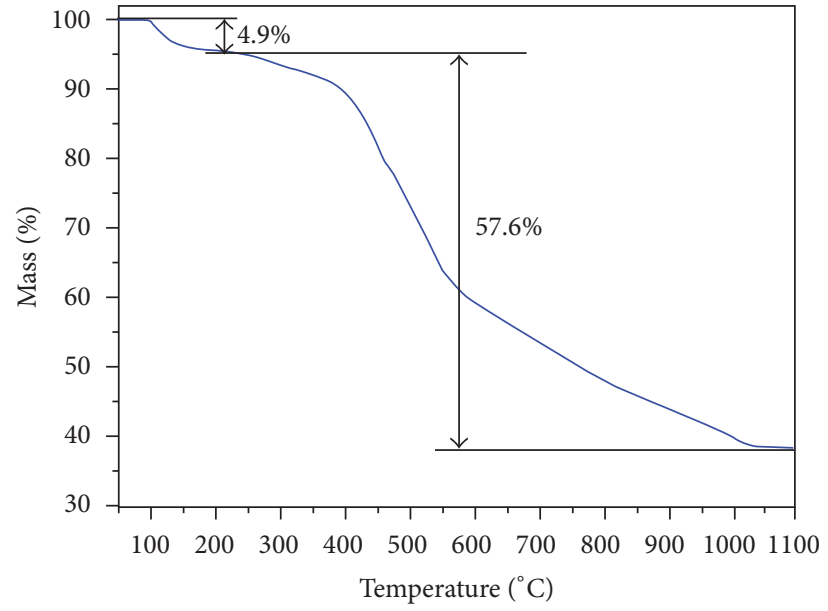

(b)

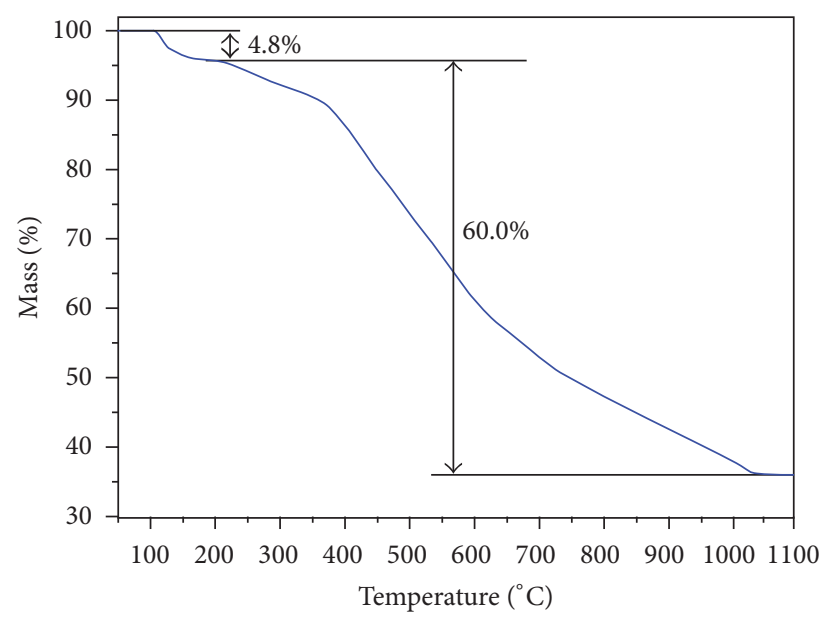

(c)

FIGURE 7: The thermal gravimetric analysis curves of (a) complex 1, (b) complex 2, and (c) complex 3. 


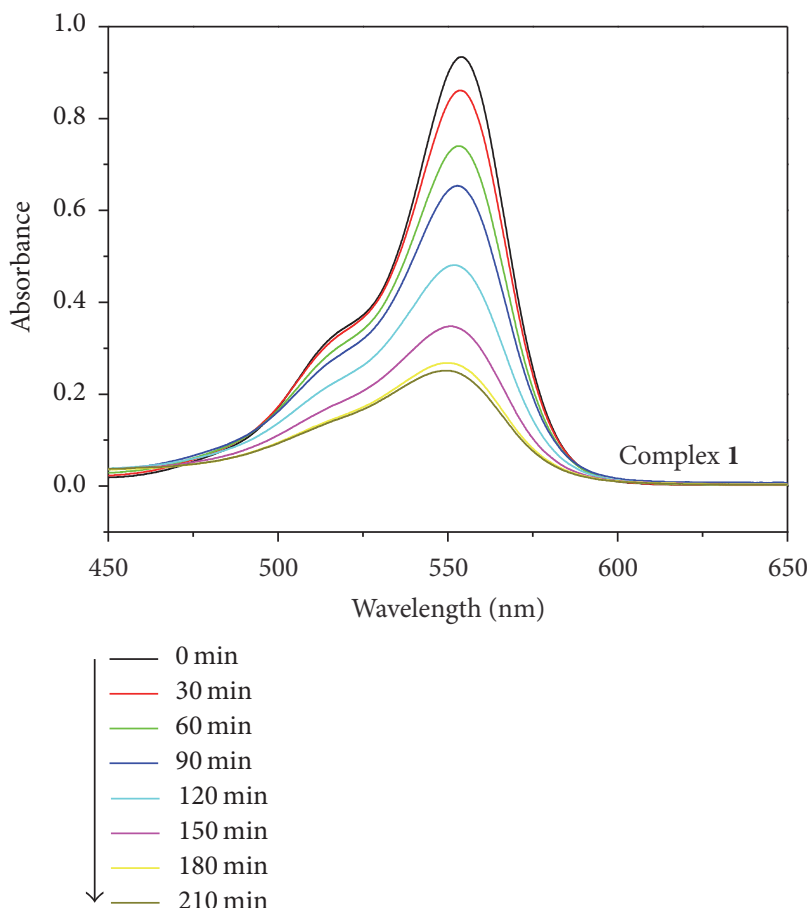

(a)

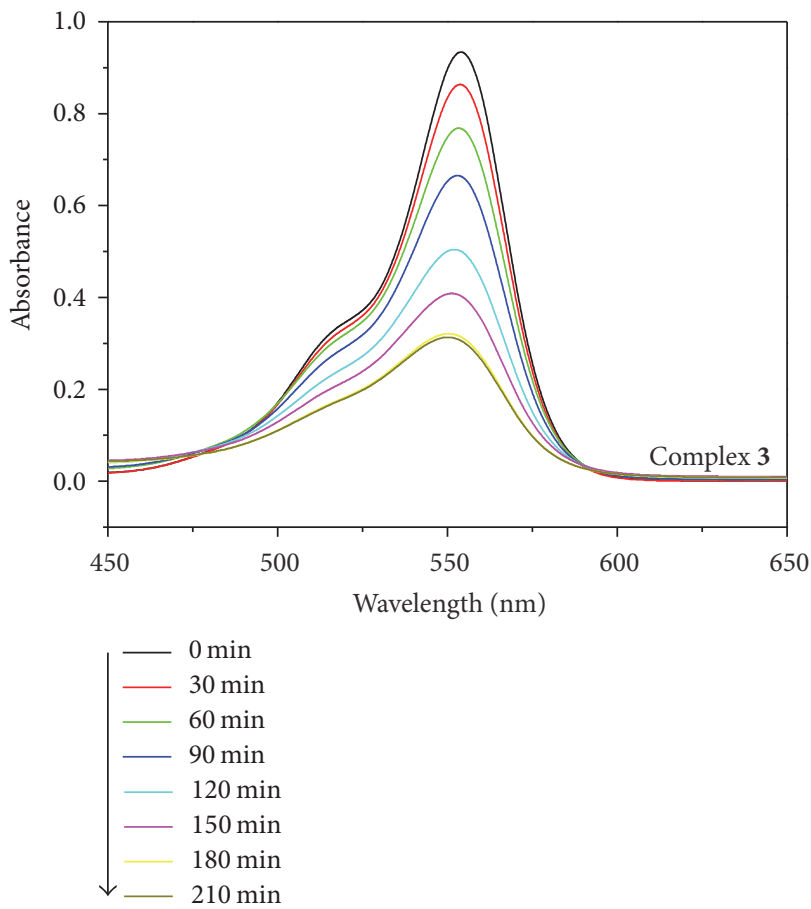

(c)

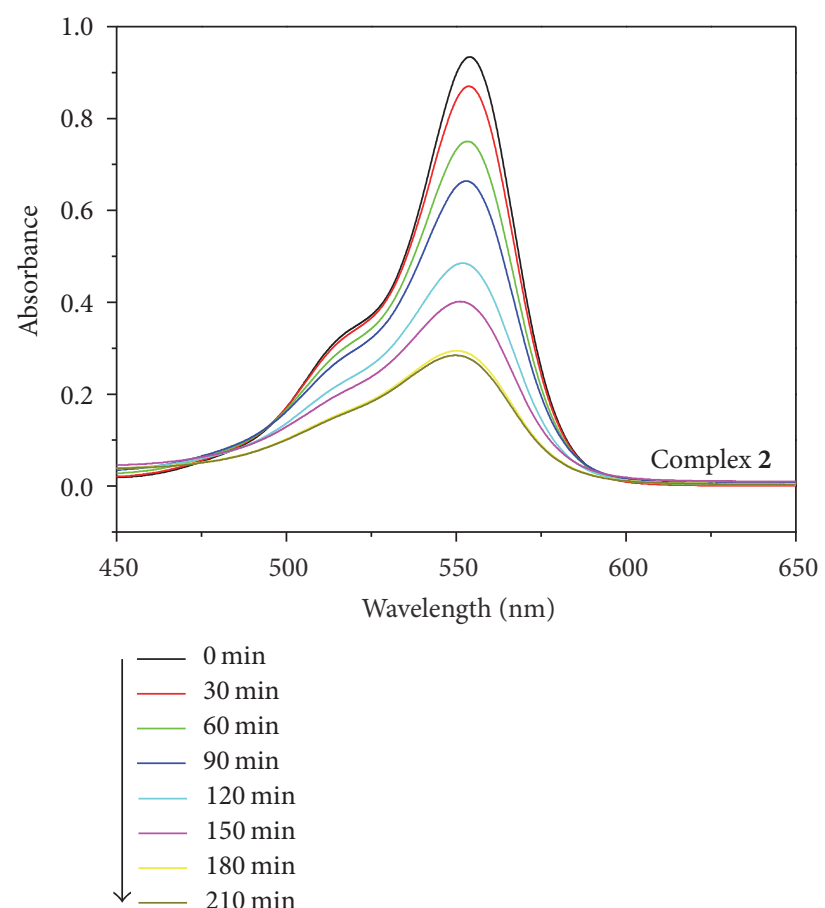

(b)

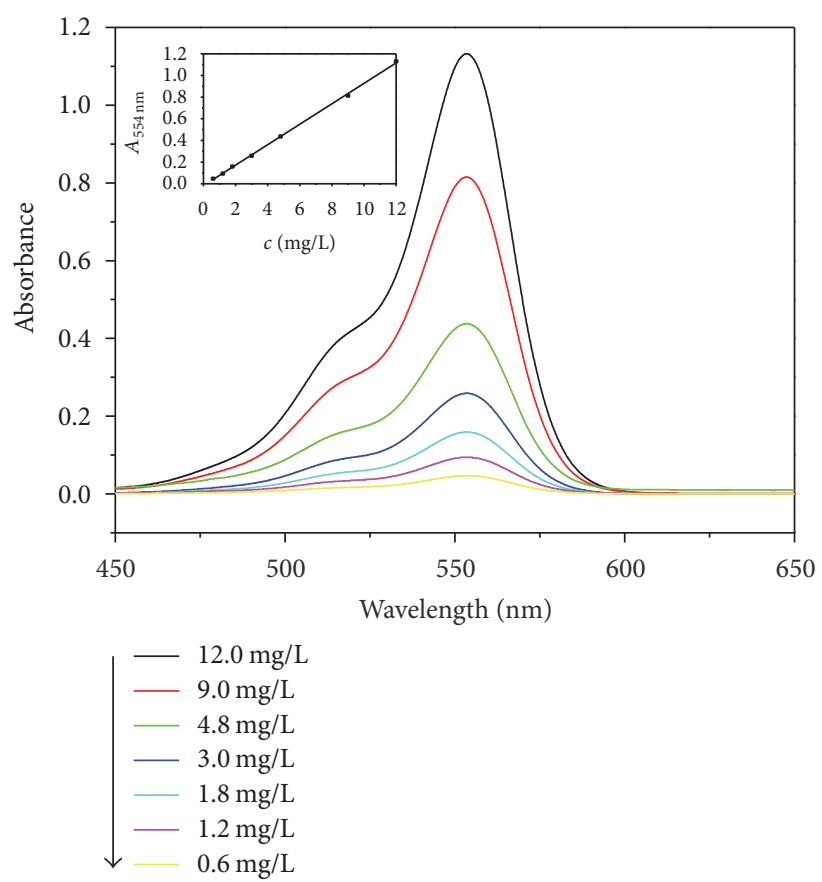

(d)

FIGURE 8: (a) The UV-vis absorption spectra of RhB solution during the photodegradation reaction when complex 1 was used as catalyst; (b) the UV-vis absorption spectra of RhB solution during the photodegradation reaction when complex 2 was used as catalyst; (c) the UV-vis absorption spectra of RhB solution during the photodegradation reaction when complex $\mathbf{3}$ was used as catalyst; (d) the standard curve of $\mathrm{RhB}$ solution. 


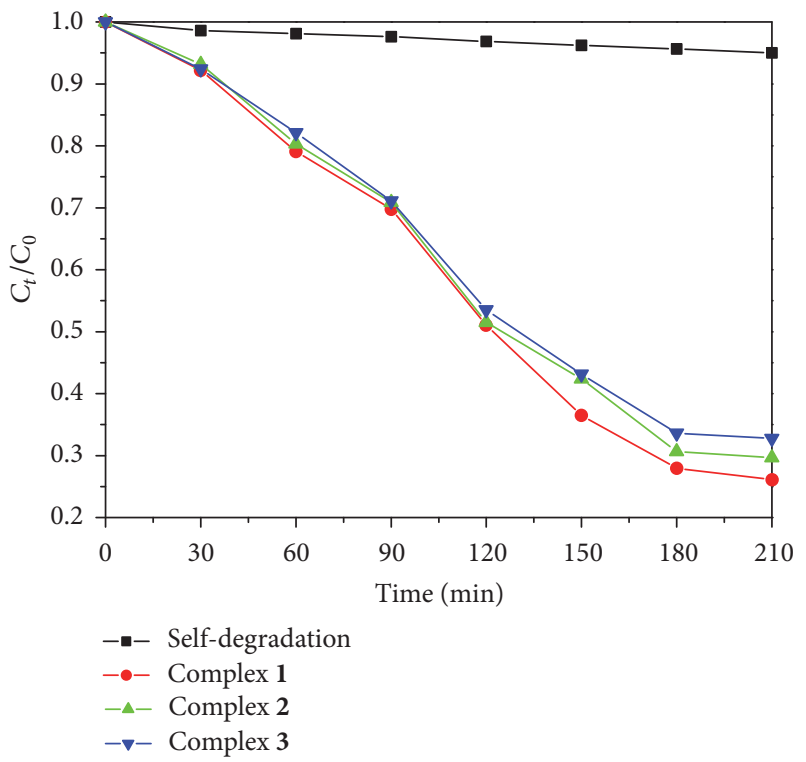

(a)

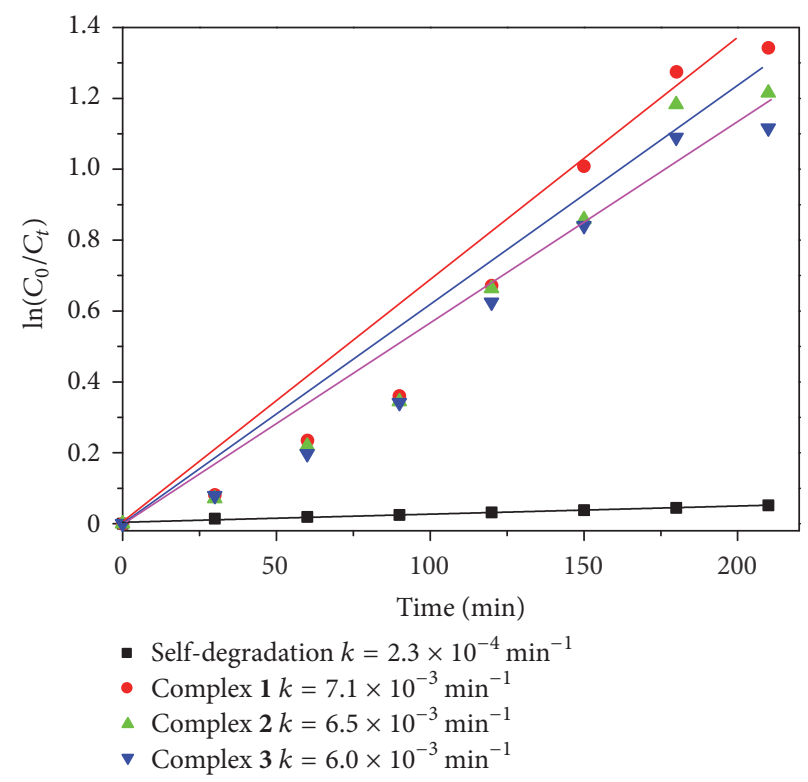

(b)

FIGURE 9: (a) Photocatalytic degradation; (b) photocatalytic degradation reaction of RhB under UV light irradiation over complexes 1-3.

irradiation under UV light, suggesting that the solution contains no photocatalytically active species. However, in the presence of complexes $\mathbf{1 - 3}$, the $\mathrm{RhB}$ in the solution is degraded approximately $74 \%, 71 \%$, and $67 \%$, respectively. From the photodegradation constant $k$ in Figure 9(b), we can see that the performance of complexes 1-3 $\left(k=7.1 \times 10^{-3}, 6.5 \times\right.$ $10^{-3}$, and $6.0 \times 10^{-3} \mathrm{~min}^{-1}$, resp.) is higher than commercially available $\mathrm{TiO}_{2}\left(k=5.9 \times 10^{-3} \mathrm{~min}^{-1}\right)$ [39]. The result indicated that the degeneration process was efficient. Meanwhile, complex 1 is higher than other complexes. Because complexes 1-3 are similar in coordination environment with similar accessibility to active uranyl centers, the higher efficiency is presumably due to the higher content of active uranyl centers in complexes 1-3 (36.2\%, 34.9\%, and 33.6\%, resp.)

It is well known that the uranyl complexes could degrade the organic pollutants mainly due to the active uranyl centers. At present, two photodegradation mechanisms, hydrogen abstraction and electron transfer, have been generally accepted for the photocatalytic reactions involving uranyl species (Figure 10) [12]. Upon photoexcitation, electrons may be promoted from the HOMO to the LUMO to generate excited ${ }^{*} \mathrm{UO}_{2}{ }^{2+}$ species. And the HOMO and LUMO were ascribed to occupied $2 \mathrm{p}$ orbitals of oxygen and the empty uranium orbitals, respectively. The excited electron in the LUMO was not stable; it may return to the HOMO instantly. However, if the electrons from organic molecules (such as $\mathrm{RhB}$ ) could be abstracted by the ${ }^{*} \mathrm{UO}_{2}{ }^{2+}$ species, resulting in organic intermediates and protons, the excited electrons in the uranyl unit would remain in the LUMO until they were captured by electronegative substances, such as $\mathrm{O}_{2}$ in the solution. Once $\mathrm{O}_{2}$ captured excited electrons, highly active peroxide anions could be formed. The organic intermediates were decomposed; as a result, peroxide anions further oxidize in the solution.

\section{Conclusions}

The $\beta$-diketonates biscatecholamide ligands $\mathrm{H}_{4} \mathrm{~L}^{1-3}$ were obtained via the reported procedure; their complexes with $\mathrm{UO}_{2}{ }^{2+}$ were also prepared successfully and determined by the means of UV-vis spectra, FTIR spectra, ${ }^{1} \mathrm{H}$ NMR, and elemental analyses. The complex ${ }^{1} \mathrm{H}$ NMR spectra show that the uranyl complexes have two conceivable geometrical isomers. The photodegradation property of the target complexes was investigated by the $\mathrm{RhB}$ which is a model compound of organic pollutant. The results show that complexes 1-3 exhibit good photocatalytic property, which will be used as the promising candidate photocatalytic materials for nuclear organic waste treatment in nuclear industry.

\section{Competing Interests}

The authors declare no conflict of interests.

\section{Authors' Contributions}

Bo Jin and Qingchun Zhang conceived and designed the experiments; Qingchun Zhang and Xiaofang Wang performed the experiments; Qingchun Zhang, Zhaotao Shi, Shan Lei, Hua Liang, and Qiangqiang Liu analyzed the data; Rufang Peng and Bo Jin contributed reagents/materials/analysis tools; Qingchun Zhang and Bo Jin wrote the paper.

\section{Acknowledgments}

The authors are grateful for financial support from the National Natural Science Foundation of China (Project no. 51572230), Open Project of State Key Laboratory Cultivation 

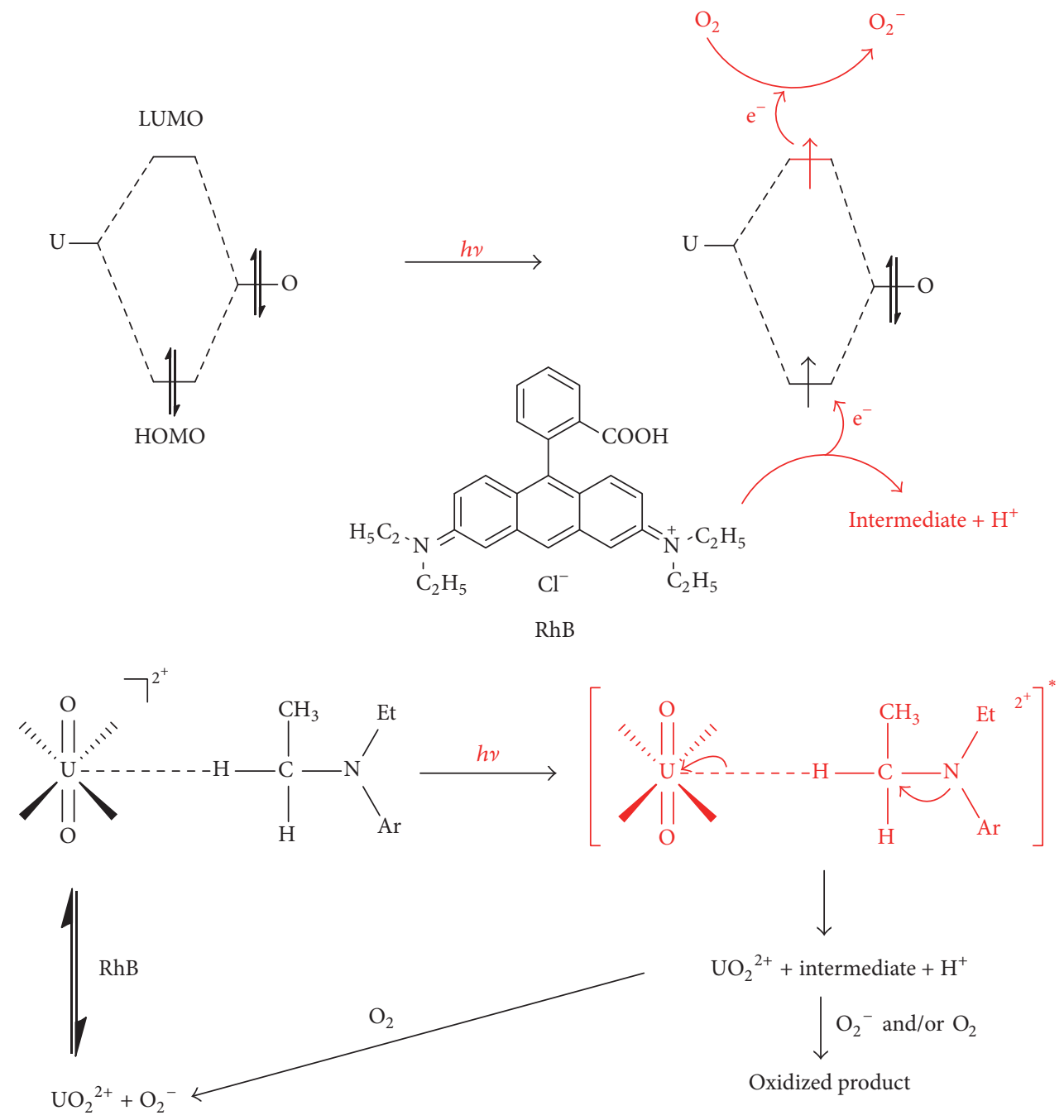

FIGURE 10: Proposed photocatalytic reaction mechanism of RhB in the presence of a uranyl complex.

Base for Nonmetal Composites and Functional (Project no. 14zdfk05), Major Project of the Education Department of Sichuan Province (Project no. 13ZA0172), and Southwest University of Science and Technology Outstanding Youth Foundation (Project no. 13zx9107).

\section{References}

[1] J. L. Sessler, P. J. Melfi, and G. D. Pantos, "Uranium complexes of multidentate $\mathrm{N}$-donor ligands," Coordination Chemistry Reviews, vol. 250, no. 7-8, pp. 816-843, 2006.

[2] J. Xu and K. N. Raymond, "Uranyl sequestering agents: Correlation of properties and efficacy with structure for $\mathrm{UO}_{2}^{2+}$ complexes of linear tetradentate 1-methyl-3-hydroxy-2(1H)pyridinone ligands," Inorganic Chemistry, vol. 38, no. 2, pp. 308315, 1999.

[3] X.-T. Xu, Y.-N. Hou, S.-Y. Wei et al., " $\mathrm{UO}_{2}{ }^{2+}$-amino hybrid materials: structural variation and photocatalysis properties," CrystEngCommunity, vol. 17, no. 3, pp. 642-652, 2015.

[4] Y. N. Hou, Z. N. Wang, F. Y. Bai et al., "Three novel $\mathrm{d}^{7} /$ $\mathrm{d}^{10}$ metal complexes with $N$-heterocyclic ligand of 2,6-bis(3pyrazolyl)pyridine: synthesis, structure, surface photovoltage spectroscopy and photocatalytic activity," RSC Advances, vol. 4, no. 41, pp. $21180-21189,2014$.

[5] P. O. Adelani and T. E. Albrecht-Schmitt, "Metal-controlled assembly of uranyl diphosphonates toward the design of functional uranyl nanotubules," Inorganic Chemistry, vol. 50, no. 23, pp. 12184-12191, 2011.

[6] Q. C. Zhang, B. Jin, R. F. Peng, S. Lei, and S. J. Chu, "Symmetrical 1,3-dicarbonyl biscatecholamide ligands as sequestering agents for uranyl decorporation," Polyhedron, vol. 87, no. 17, pp. 417423, 2015.

[7] L. R. Melby, N. J. Rose, E. Abramson, and J. C. Caris, "Synthesis and fluorescence of some trivalent lanthanide complexes," Journal of the American Chemical Society, vol. 86, no. 23, pp. 5117-5125, 1964.

[8] J. L. Burdett and M. T. Rogers, "Keto-enol tautomerism in $\beta$-dicarbonyls studied by nuclear magnetic resonance spectroscopy. I. Proton chemical shifts and equilibrium constants of pure compounds," Journal of the American Chemical Society, vol. 86, no. 11, pp. 2105-2109, 1964.

[9] P. W. Durbin, B. Kullgren, S. N. Ebbe, J. Xu, and K. N. Raymond, "Chelating agents for uranium(VI): 2. Efficacy and toxicity of 
tetradentate catecholate and hydroxypyridinonate ligands in mice," Health Physics, vol. 78, no. 5, pp. 511-521, 2000.

[10] F. L. Weitl and K. N. Raymond, "Specific sequestering agents for the actinides. 3. Polycatecholate ligands derived from 2,3dihydroxy-5-sulfobenzoyl conjugates of diaza- and tetraazaalkanes," Journal of the American Chemical Society, vol. 102, no. 7, pp. 2289-2293, 1980.

[11] S. B. Nam, H. K. Yong, and K. K. Hwan, "Rational design, exploratory synthesis and lanthanide emission efficiency comparison of lanthanide(III)-cored complexes based on naphthalene acid ligands for efficient energy transfer pathways," Bulletin of the Korean Chemical Society, vol. 27, no. 11, pp. 1729-1730, 2006.

[12] H. D. Burrows and T. J. Kemp, "The photochemistry of the uranyl ion," Chemical Society Reviews, vol. 3, no. 2, pp. 139-165, 1974.

[13] T. M. McCleskey, C. J. Burns, and W. Tumas, "Uranyl photochemistry with alkenes: distinguishing between $\mathrm{H}$-atom abstraction and electron transfer," Inorganic Chemistry, vol. 38, no. 25, pp. 5924-5925, 1999.

[14] M. Sarakha, M. Bolte, and H. D. Burrows, “The photo-oxidation of 2,6-dimethylphenol and monophenylphenols by uranyl ion in aqueous solution," Journal of Photochemistry and Photobiology A: Chemistry, vol. 107, no. 1-3, pp. 101-106, 1997.

[15] K. A. Walters, D. A. Gaal, and J. T. Hupp, "Interfacial charge transfer and colloidal semiconductor dye-sensitization: mechanism assessment via Stark emission spectroscopy," The Journal of Physical Chemistry B, vol. 106, no. 20, pp. 5139-5142, 2002.

[16] K. E. Splan, A. M. Massari, and J. T. Hupp, "A porous multilayer dye-based photoelectrochemical cell that unexpectedly runs in reverse," The Journal of Physical Chemistry B, vol. 108, no. 13, pp. 4111-4115, 2004.

[17] V. A. Volkovich, T. R. Griffiths, D. J. Fray, and R. C. Thied, "The electronic spectra of alkali metal uranates and band assignments: an analysis of their diffuse reflectance spectra," Physical Chemistry Chemical Physics, vol. 3, no. 23, pp. 51825191, 2001.

[18] R. S. Addleman, M. Carrott, C. M. Wai, T. E. Carleson, and B. W. Wenclawiak, "On-line speciation of uranyl chelates in supercritical $\mathrm{CO}_{2}$ by time-resolved laser-induced fluorescence spectroscopy," Analytical Chemistry, vol. 73, no. 6, pp. 1112-1119, 2001.

[19] J. Huang, X. Q. Wang, and A. J. Jacobson, "Hydrothermal synthesis and structures of the new open-framework uranyl silicates $\mathrm{Rb}_{4}\left(\mathrm{UO}_{2}\right)_{2}\left(\mathrm{Si}_{8} \mathrm{O}_{20}\right)(\mathrm{USH}-2 \mathrm{Rb}), \mathrm{Rb}_{2}\left(\mathrm{UO}_{2}\right)\left(\mathrm{Si}_{2} \mathrm{O}_{6}\right) \cdot \mathrm{H}_{2} \mathrm{O}$ (USH-4Rb) and $\mathrm{A}_{2}\left(\mathrm{UO}_{2}\right)\left(\mathrm{Si}_{2} \mathrm{O}_{6}\right) \cdot 0.5 \mathrm{H}_{2} \mathrm{O}$ (USH-5A; $\mathrm{A}=\mathrm{Rb}$, Cs)," Journal of Materials Chemistry, vol. 13, no. 2, pp. 191-196, 2003.

[20] H. Zheng, C. K. Lai, and T. M. Swager, "Controlling intermolecular interactions between metallomesogens: side-chain effects in discotic copper, palladium, and vanadyl bis( $\beta$-diketonates)," Chemistry of Materials, vol. 7, no. 11, pp. 2067-2077, 1995.

[21] H. Sato, H. Uno, and H. Nakano, "Identification of geometrical isomers using vibrational circular dichroism spectroscopy: a series of mixed-ligand complexes of diamagnetic $\mathrm{Co}$ (III) ions," Dalton Transactions, vol. 40, no. 6, pp. 1332-1337, 2011.

[22] H. Miyake, K. Terada, and H. Tsukube, "Lanthanide tris $(\beta$ diketonates) as useful probes for chirality determination of biological amino alcohols in vibrational circular dichroism: ligand to ligand chirality transfer in lanthanide coordination sphere," Chirality, vol. 26, no. 6, pp. 293-299, 2014.
[23] A. D. Buckingham, "Chemical shifts in the nuclear magnetic resonance spectra of molecules containing polar groups," Canadian Journal of Chemistry, vol. 38, no. 2, pp. 300-307, 1960.

[24] A. E. V. Gorden, J. Xu, K. N. Raymond, and P. Durbin, "Rational design of sequestering agents for plutonium and other actinides," Chemical Reviews, vol. 103, no. 11, pp. 4207-4282, 2003.

[25] X. Kong, Y. Ren, L. Long, R. Huang, and L. Zheng, "An organicinorganic hybrid uranyl nicotinate molybdate polymer and its fluorescent property," Inorganic Chemistry Communications, vol. 10, no. 8, pp. 894-896, 2007.

[26] Z.-T. Yu, Z.-L. Liao, Y.-S. Jiang, G.-H. Li, and J.-S. Chen, "Water-insoluble Ag-U-organic assemblies with photocatalytic activity," Chemistry, vol. 11, no. 9, pp. 2642-2650, 2005.

[27] Z. Hnatejko, S. Lis, Z. Stryia, and P. Starynowicz, "Structural and spectroscopy studies of complexes of the uranyl ion with $2,2^{\prime}$ bipyridine-N, $\mathrm{N}^{\prime}$-dioxide," Polyhedron, vol. 29, no. 9, pp. 20812086, 2010

[28] N. M. Shavaleev, R. Scopelliti, F. Gumy, and J.-C. G. Bünzli, "Visible-light excitation of infrared lanthanide luminescence via intra-ligand charge-transfer state in 1,3-diketonates containing push-pull chromophores," European Journal of Inorganic Chemistry, no. 9, pp. 1523-1529, 2008.

[29] N. S. Baek, Y. H. Kim, Y. K. Eom et al., "Sensitized nearIR luminescence of lanthanide complexes based on push-pull diketone derivatives," Dalton Transactions, vol. 39, no. 6, pp. 1532-1538, 2010.

[30] T. J. Pinnavaia and R. C. Fay, "Nuclear magnetic resonance studies of ligand exchange for some group IVb $\beta$-diketonates," Inorganic Chemistry, vol. 5, no. 2, pp. 233-239, 1966.

[31] C. Bruner, F. Novoa, S. Dupont, and R. Dauskardt, "Decohesion kinetics in polymer organic solar cells," ACS Applied Materials and Interfaces, vol. 6, no. 23, pp. 21474-21483, 2014.

[32] J. Zhang, X. Zhang, G. Li et al., "Enhancing the performance of polymer solar cells by tuning the drying process of blend films via changing side chains and using solvent additives," Journal of Materials Chemistry C, vol. 3, no. 37, pp. 9670-9677, 2015.

[33] S. Van den Berghe, F. Miserque, T. Gouder, B. Gaudreau, and M. Verwerft, "X-ray photoelectron spectroscopy on uranium oxides: a comparison between bulk and thin layers," Journal of Nuclear Materials, vol. 294, no. 1-2, pp. 168-174, 2001.

[34] S. Chen, J. Hong, H. Yang, and J. Yang, "Adsorption of uranium (VI) from aqueous solution using a novel graphene oxideactivated carbon felt composite," Journal of Environmental Radioactivity, vol. 126, pp. 253-258, 2013.

[35] M. Schindler, F. C. Hawthorne, M. S. Freund, and P. C. Burns, "XPS spectra of uranyl minerals and synthetic uranyl compounds. II: the O 1s spectrum," Geochimica et Cosmochimica Acta, vol. 73, no. 9, pp. 2488-2509, 2009.

[36] J.-C. Geng, L. Qin, X. Du, S.-L. Xiao, and G.-H. Cui, "Synthesis, crystal structures, and catalytic properties of silver(I) and cobalt(II) coordination polymers based on flexible bis(benzimidazole) with pyridine-2, 6-dicarboxylate," Zeitschrift fur Anorganische und Allgemeine Chemie, vol. 638, no. 7-8, pp. 1233-1238, 2012.

[37] E. Haque, J. E. Lee, I. T. Jang et al., "Adsorptive removal of methyl orange from aqueous solution with metal-organic frameworks, porous chromium-benzenedicarboxylates," Journal of Hazardous Materials, vol. 181, no. 1-3, pp. 535-542, 2010.

[38] L. Qin, S. L. Xiao, P. J. Ma, and G. H. Cui, "Synthesis, crystal structures and catalytic properties of $\mathrm{Ag}(\mathrm{I})$ and $\mathrm{Co}(\mathrm{II})$ 
1D coordination polymers constructed from bis(benzimidazolyl)butane," Transition Metal Chemistry, vol. 38, no. 6, pp. 627-633, 2013.

[39] W. Y. Gao, M. Q. Wang, C. X. Ran, and L. Li, "Facile one-pot synthesis of $\mathrm{MoS}_{2}$ quantum dots-graphene- $\mathrm{TiO}_{2}$ composites for highly enhanced photocatalytic properties," Chemical Communications, vol. 51, no. 9, pp. 1709-1712, 2015. 

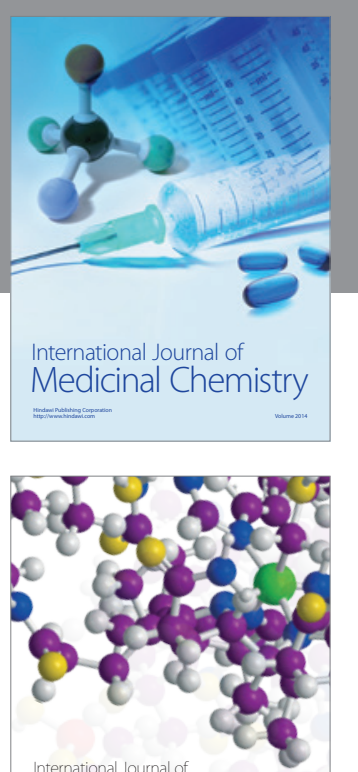

Carbohydrate Chemistry

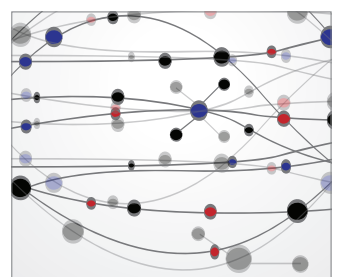

The Scientific World Journal
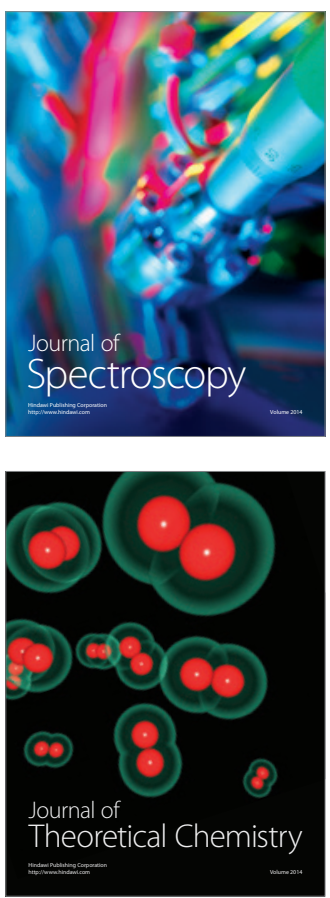
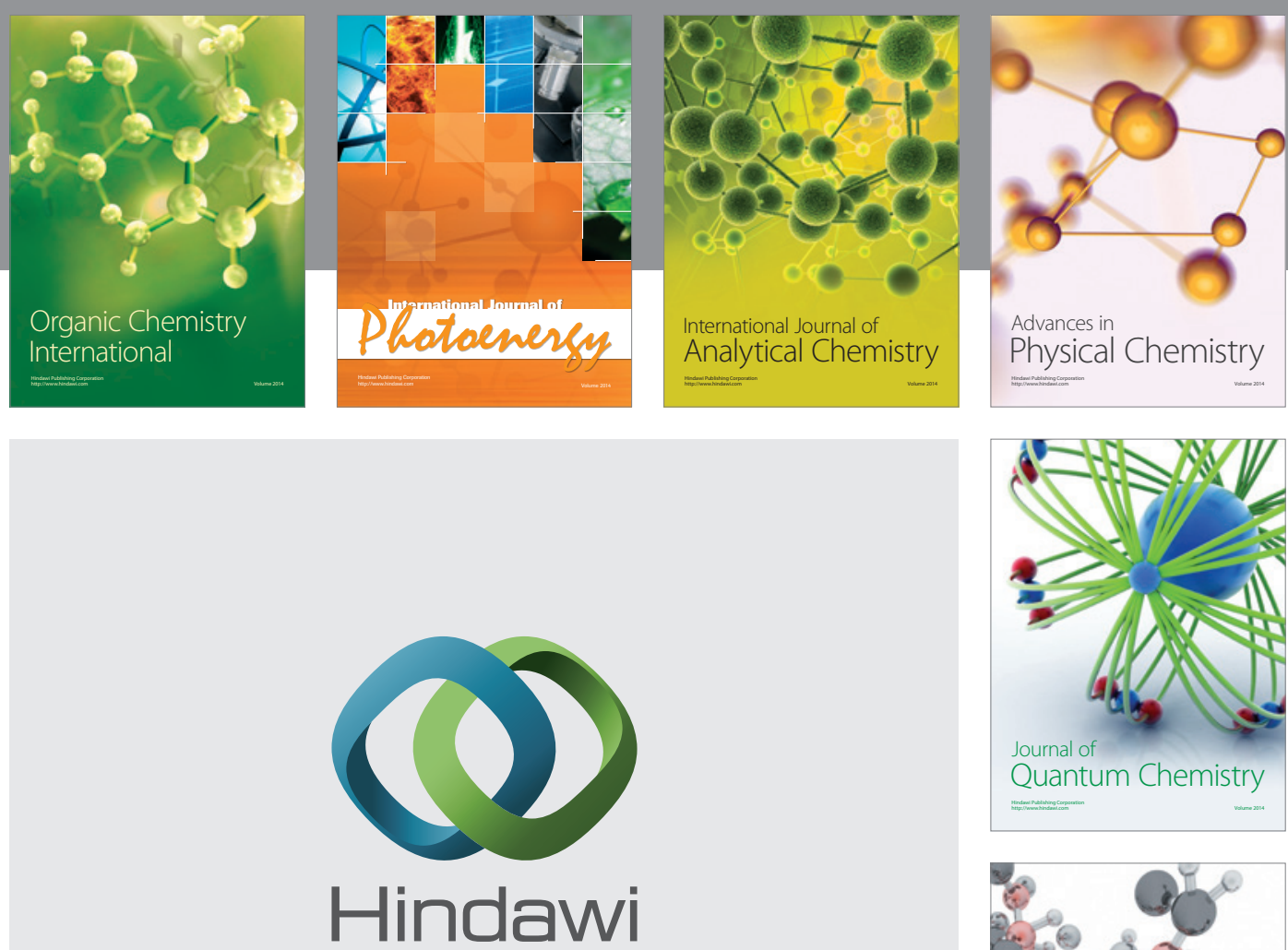

Submit your manuscripts at

https://www.hindawi.com

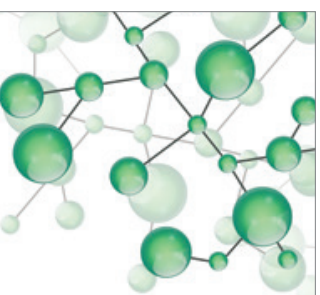

International Journal of

Inorganic Chemistry
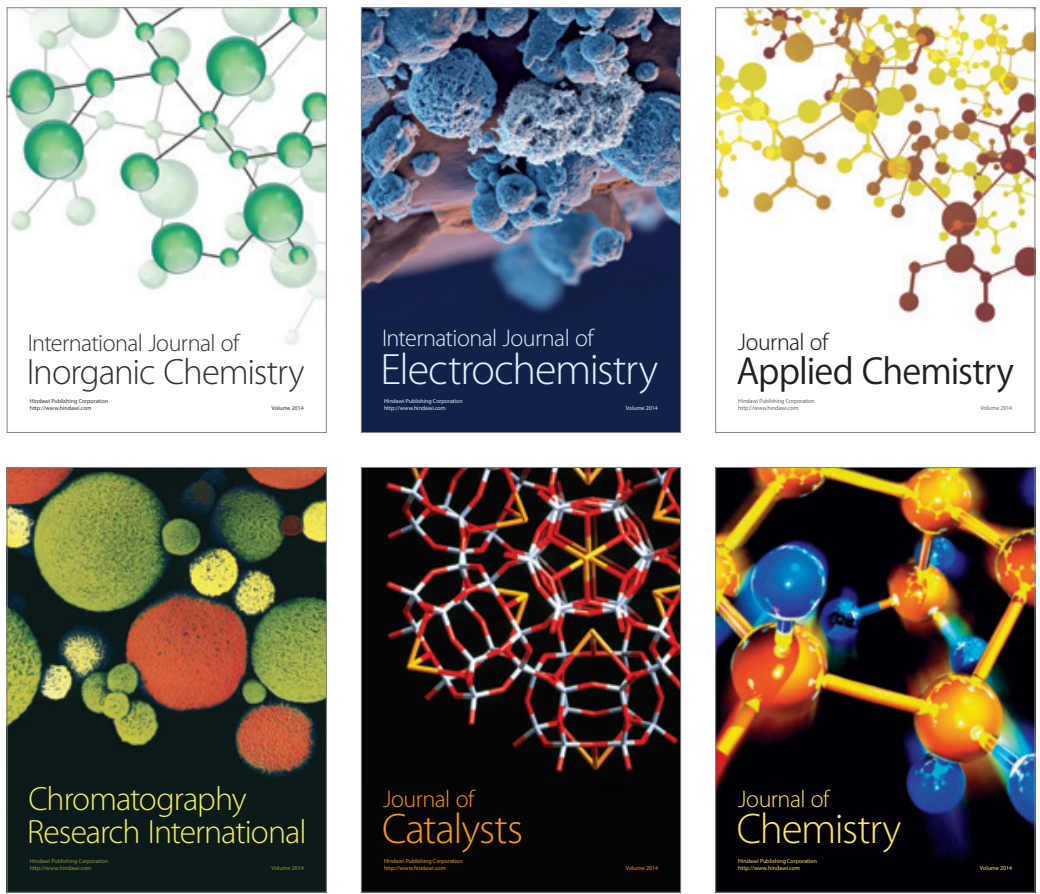

Journal of

Applied Chemistry
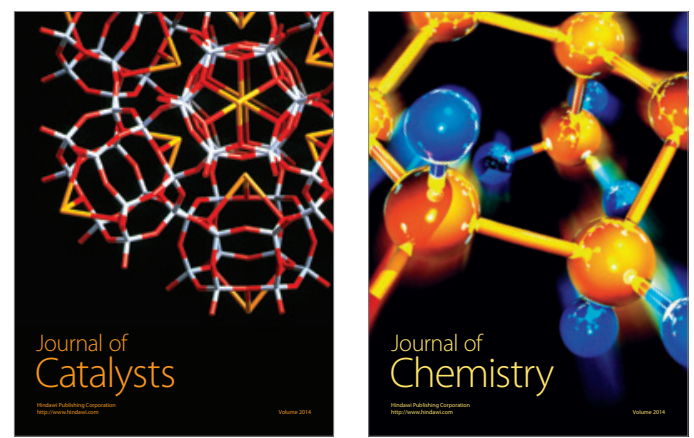
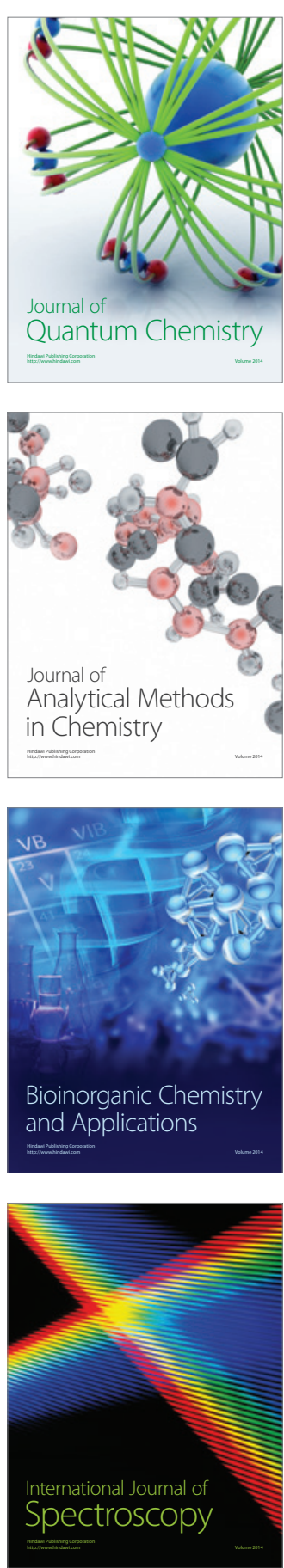